Illinois State University

ISU ReD: Research and eData

Theses and Dissertations

7-27-2013

\title{
Secondary Education Teacher Preparation Programs Should Differentiate Curriculum and Instruction for Traditional and Nontraditional Preservice Teachers
}

Cynthia Jane Schairer-Kessler

Illinois State University, schairercj@aol.com

Follow this and additional works at: https://ir.library.illinoisstate.edu/etd

Part of the Teacher Education and Professional Development Commons

\section{Recommended Citation}

Schairer-Kessler, Cynthia Jane, "Secondary Education Teacher Preparation Programs Should Differentiate Curriculum and Instruction for Traditional and Nontraditional Preservice Teachers" (2013). Theses and Dissertations. 15.

https://ir.library.illinoisstate.edu/etd/15

This Dissertation is brought to you for free and open access by ISU ReD: Research and eData. It has been accepted for inclusion in Theses and Dissertations by an authorized administrator of ISU ReD: Research and eData. For more information, please contact ISUReD@ilstu.edu. 


\title{
SECONDARY EDUCATION TEACHER PREPARATION PROGRAMS SHOULD DIFFERENTIATE CURRICULUM AND INSTRUCTION FOR TRADITIONAL AND NONTRADITIONAL PRESERVICE TEACHERS
}

\author{
Cynthia J. Schairer-Kessler
}

117 Pages

August 2013

A quantitative study of traditional and nontraditional preservice student teachers at the secondary level at Illinois State University. 


\title{
SECONDARY EDUCATION TEACHER PREPARATION PROGRAMS SHOULD DIFFERENTIATE CURRICULUM AND INSTRUCTION FOR TRADITIONAL
} AND NONTRADITIONAL PRESERVICE TEACHERS

\author{
Cynthia J. Schairer-Kessler
}

\section{Pages}

August 2013

Much demand remains for teacher education programs to produce highly qualified teachers. Current trends show that almost half of today's preservice teachers are considered nontraditional in terms of age and life experience. The purpose of this study was to determine whether secondary education teacher preparation programs should differentiate curriculum and instruction for traditional and nontraditional preservice teachers. Research questions incorporated four variables of professional demeanor, teaching and learning, interpersonal skills, and time management. Data was collected through a presurvey at the beginning of the student teaching semester and a postsurvey at the end of the semester, as well as an analysis of student teachers' Student Teaching Assessments. Forty-three preservice student teachers responded to the presurvey; of those forty three, twenty-two responded to the postsurvey. Of those twenty-two respondents, fourteen allowed access to their Student 
Teaching Assessments. About half of the respondents were considered nontraditional according to their birthdates. Data was averaged and then compared using a two-sample t-test. While the sample was very small, differences between the two groups did emerge. The nontraditional group performed better on the teaching and learning part of their evaluations than the traditional group. In addition, the nontraditional group had less trouble with classroom management than the traditional group. Interestingly, while the nontraditional group managed their time better than the traditional group, they underestimated the amount of time they would spend on student-teaching tasks outside the school. Implications for future research include a retest to attempt a larger sample size, a test of elementary preservice teachers, and a test at another teacher education program. Additionally, the nontraditional group can be investigated more closely to determine whether further differentiation would be beneficial for preservice teachers who are parents or had served in the military. 
SECONDARY EDUCATION TEACHER PREPARATION PROGRAMS SHOULD DIFFERENTIATE CURRICULUM AND INSTRUCTION FOR TRADITIONAL AND NONTRADITIONAL PRESERVICE TEACHERS

CYNTHIA J. SCHAIRER-KESSLER

A Dissertation Submitted in Partial Fulfillment of the Requirements for the Degree of DOCTOR OF EDUCATION

Department of Teaching and Learning ILLINOIS STATE UNIVERSITY 
Copyright 2013 Cynthia J. Schairer-Kessler 
SECONDARY EDUCATION TEACHER PREPARATION PROGRAMS SHOULD DIFFERENTIATE CURRICULUM AND INSTRUCTION FOR TRADITIONAL AND NONTRADITIONAL PRESERVICE TEACHERS

CYNTHIA J. SCHAIRER-KESSLER

DISSERTATION APPROVED:

Date Nancy I. Latham, Chair

Date Douglas D. Hatch

Date Steven Mertens

Date Cynthia L. Wilson 


\section{ACKNOWLEDGEMENTS}

I wish to acknowledge the scholars and mentors who helped me find my way. This includes a special mention to Dr. Nancy Latham for graciously agreeing to chair the committee, Dr. Steven Mertens for his methodology help, Dr. Douglas Hatch for advising me to rethink my study, and Dr. Cynthia Wilson, my mentor since my student-teaching days. In addition, Dr. Thomas Crumpler and Dr. Thomas Haynes helped shape my thinking.

Too many to mention are the fine teachers I had at El Paso High School, the University of Illinois, the University of Georgia, and Illinois State University. Thanks to Lynn Steffen of the Cecilia B. Lauby Teacher Education Center, who was not only the source of my data but also my junior high math teacher.

On a personal note, l'd like to thank the BBC and my GG for their cheers and prayers; and Rachel and David Foster for childcare and statistics help.

This dissertation is dedicated to my love, Paul, who is the sole reason I got the chance to pursue my doctorate; to my mother, Sandra, who instilled in me a deep love of teaching and learning; and to my sons William and Joseph who were created at the same time as this dissertation. Your infancy and early childhood will forever be entwined with the production of my study.

And finally, this dissertation is presented in memory of my father, Wink, who was lost to us two weeks before my first doctoral class. I know he is proud. 
CONTENTS

Page

ACKNOWLEDGEMENTS

CONTENTS ii

TABLES

CHAPTER

I. THE PROBLEM AND ITS BACKGROUND 1

Statement of the Problem 1

Novice Teachers $\quad 2$

Learning Theories 3

Time Management Theory 5

Teacher Preparation at Illinois State University $\quad 6$

$\begin{array}{ll}\text { Purpose of the Study } & 7\end{array}$

Research Questions $\quad 8$

Hypotheses $\quad 9$

Definitions 10

Limitations of the Study $\quad 12$

II. REVIEW OF LITERATURE 13

Highly Qualified Teachers $\quad 14$

Novice Teachers $\quad 15$

$\begin{array}{ll}\text { Teacher Preparation Programs } & 17\end{array}$

Teacher Preparation Curriculum 18

Teacher Preparation Instruction 20

Alternative Certification $\quad 23$

$\begin{array}{ll}\text { Preservice Teachers } & 24\end{array}$ 
Traditional Students $\quad 25$

Nontraditional Students $\quad 26$

Student Teachers $\quad 29$

Cooperating Teachers 30

University Supervisors 31

Field Experiences 31

Student Teaching 32

Time Management Theory 33

$\begin{array}{ll}\text { Conclusion } & 34\end{array}$

III. METHODOLOGY AND PROCEDURES 36

Research Design 36

$\begin{array}{ll}\text { Participants } & 37\end{array}$

Subjects $\quad 37$

Human Subjects' Consideration 38

Sample Selection $\quad 39$

Power Analysis $\quad 40$

Participation Rate $\quad 41$

Variables $\quad 42$

Instruments $\quad 43$

RDI Student Teaching Assessment 43

Preservice Teacher Perception Survey $\quad 46$

Validity and Reliability $\quad 51$

Statistical Procedure $\quad 53$

Limitations of the Study $\quad 56$

Conclusion $\quad 57$

IV. RESULTS 58

Participants $\quad 58$

$\begin{array}{ll}\text { Research Questions } & 61\end{array}$

Research Question $1 \quad 62$

Research Question $2 \quad 63$

Research Question $3 \quad 64$

Research Question $4 \quad 65$

Research Question $5 \quad 68$

Research Question $6 \quad 71$

$\begin{array}{ll}\text { Limitations } & 75\end{array}$ 
$\begin{array}{ll}\text { Summary } & 76\end{array}$

V. DISCUSSION AND IMPLICATIONS 77

$\begin{array}{ll}\text { Research Questions } & 77\end{array}$

$\begin{array}{ll}\text { Research Question } 1 & 77\end{array}$

Results $\quad 77$

Implications $\quad 78$

Research Question 2

Results $\quad 79$

Implications $\quad 79$

$\begin{array}{lr}\text { Research Question } 3 & 80\end{array}$

Results $\quad 80$

Implications $\quad 81$

Research Question $4 \quad 81$

Results $\quad 82$

Implications $\quad 82$

Research Question 5

Results $\quad 83$

Implications $\quad 84$

Research Question $6 \quad 84$

Results $\quad 84$

Implications $\quad 86$

$\begin{array}{ll}\text { Conclusions } & 87\end{array}$

Recommendations for Future Research 88

$\begin{array}{ll}\text { REFERENCES } & 90\end{array}$

$\begin{array}{lll}\text { APPENDIX A: } & \begin{array}{l}\text { Realizing the Democratic Ideal } \\ \text { Student Teaching Assessment }\end{array} & 100\end{array}$

APPENDIX B: $\quad$ Preservice Teacher Perception Survey 110 


\section{TABLES}

Table

Page

1. Professional Demeanor Constructs on the RDI Student Teaching Assessment

2. Teaching and Learning Constructs on the RDI Student Teaching Assessment

3. Interpersonal Skills Constructs on the RDI Student Teaching Assessment

4. Professional Demeanor Constructs on the Preservice Teacher Perception Survey

5. Teaching and Learning Constructs on the Preservice Teacher Perception Survey

6. Interpersonal Skills Constructs on the Preservice Teacher Perception Survey

7. Time Management Constructs on the Preservice Teacher Perception Survey

8. Presurvey Respondent Demographics

9. Postsurvey Respondent Demographics 60

10. RDI Student Teaching Assessment Participants 61

11. Research Question 1 Results for Professional Demeanor Evaluation

12. Research Question 2 Results for Teaching and Learning Evaluation

13. Research Question 3 Results for Interpersonal Skills Evaluation 
14. Research Question 4 Results for Time

Management Presurvey

15. Research Question 4 Results for Time Management Postsurvey

16. Research Question 4 Results for t-test, Time Management

17. Research Question 5 Results for t-test, Professional Demeanor

18. Research Question 5 Results for t-test, Teaching and Learning

19. Research Question 5 Results for t-test, Interpersonal Skills

20. Research Question 6 Results for t-test, Professional Demeanor

21. Research Question 6 Results for t-test, Teaching and Learning

22. Research Question 6 Results for t-test, Interpersonal Skills

23. Research Question 6 Results for t-test, Time Management 


\title{
CHAPTER I \\ THE PROBLEM AND ITS BACKGROUND
}

\begin{abstract}
Statement of the Problem
College populations have been changing over the last several decades; instead of incoming freshmen being eighteen-year-olds arriving directly after graduating from high school, known as traditional students, many incoming freshmen are second-career older people, or Armed Forces veterans, or even parents who reared children before going to college themselves, known as nontraditional students (Paccion, McWhorter, \& Richburg, 2000, Lee \& Lamport, 2011, Advisory Committee on Student Financial Assistance, 2012).Teacher education programs are not immune to such population changes. While much work has gone into the creation, improvement, modification, and enhancement of the curriculum that sustains teacher education programs, it is not evident that much concern has been given to addressing potential differences in the learning needs of the two groups of teacher education students. Since the goal of collegiate teacher education programs is to produce teachers who are qualified to teach in their chosen field of expertise, such programs should assess how well they are accomplishing this goal. Perhaps traditional student teachers require a
\end{abstract}


different kind of guidance than nontraditional student teachers, but they are not getting a differentiated teacher education experience.

Novice Teachers

Year after year, as teachers retire or leave their positions for other schools or interests, across the nation schools have teaching positions available. In order to best serve their students and community, administrators at schools want to hire teachers who are highly qualified, which usually requires experience teaching (Kniseley, 2011). Novice teachers by their very definition do not have much experience teaching (Lortie, 1975; Brouwer \& Korthagen, 2005). Of course, novice teachers are not all at the same level of life experience (Lee \& Lamport, 2011). Some novice teachers are young and have entered a teacher preparation program directly upon graduating from high school. Some novice teachers are older and may have different college degrees, or careers, or other life experiences between high school and their current teacher preparation programs, perhaps including some experience substitute teaching (Novak \& Knowles, 1992).

Younger novice teachers are typically emotionally and socially less mature than older novice teachers, which can impact their attitudes and performance in the classroom (Howe \& Strauss, 2000; Tyler, 2007; Oblinger, 2003). Older novice teachers likely have additional responsibilities outside their teaching careers, which can also impact their attitudes and performance in the classroom (Baumlein, 2004; Justice \& Dornan, 2001). Finally, novice teachers experience frustration with managing their time with both planned and unplanned 
tasks (Wilcox \& Samaras, 2009). Teacher education programs strive to produce novice teachers who are prepared to teach, and so such programs place much emphasis on crafting appropriate curriculum and instruction to best prepare future novice teachers.

\section{Learning Theories}

Several theories regarding how students in teacher education programs might learn can encapsulate the concepts of differentiating the learning process for different types of students. To help describe the nontraditional college student, the theory of andragogy lends a perspective. In 1968 Malcolm Knowles published his definition of "andragogy; the art and science of helping adults learn," unlike pedagogy, which examines how children learn (Knowles, 1984, p. 6). Knowles developed five characteristics of the adult learner. These characteristics are summarized as being self-directed, having life experiences upon which to attach new learning, having learning needs based on societal roles, being a problem-solver, and being internally motivated (Merriam, 2001). However, as other scholars and Knowles himself acknowledged, children can possess some of these characteristics while not all adults possess all of the characteristics. Rather, the characteristics might be on a continuum, with "teacher-directed learning," or what is commonly known as "pedagogy" on one end and "student-directed learning," or what is commonly known as "andragogy" on the other end. He also indicated that both types of learning can be appropriate, regardless of the age of the learner, depending upon the learner's particular needs and the particular teaching situation (Merriam, 2001, p. 6). 
Contrasted with the adult learners and the andragogy best used to educate them are post-adolescent learners for whom pedagogy is the common approach professors use to educate (Kugel, 1993). Such learners are optimistic, cooperative, team players who accept authority and follow rules. They are smarter than most people think they are, and they believe in the future, seeing themselves as its cutting edge (Howe \& Strauss, 2000, p. 7). These learners are transitioning from children into adults, and so would be somewhere on the adultlearning continuum, although more on the pedagogical end than the andragogical end.

A second theory related to both andragogy and pedagogy is constructivism, a learning theory currently taught by teacher educators to future teachers. Based on Jean Piaget's work, constructivism is a manner of building or attaching new information or learning to old, learned knowledge. Students "understand something when it has meaning for them or makes sense to them" (Killen, 2007, p. 11). Educators refer to the attached, acquired knowledge as "scaffolding" upon which new information is built. One could rationalize that students with more life experiences would have more scaffolding upon which to attach new information and knowledge than people with fewer life experiences would. Just as teacher educators are teaching future teachers about the implications of scaffolding, so might teacher educators consider the implications of scaffolding for their own classes. Teacher educators might also consider that their learners could be at various points on the pedagogy-andragogy continuum. 
Twenty years ago, a secondary education teacher preparation program might have had only a couple of nontradtional students enrolled. Today, at Illinois State University, almost one third of the secondary education preservice teachers are nontraditional. Therefore, most likely almost one third of secondary education preservice teachers have more scaffolding upon which to attach new information than the other two thirds of secondary education preservice teachers. Such differences in life experiences and scaffolding can impact the way new knowledge is acquired, the type of new knowledge acquired, and the amount of new knowledge acquired. The scaffolding each student brings to the class influences the learning of each student, and subsequently, the preparation of the teacher educator.

\section{Time Management Theory}

Using time wisely as both a student and as a student teacher is important and not explicitly taught by teacher preparation programs. Although students are expected over the course of their undergraduate program to plan for their time and get assignments turned in for grading on time, no required class in the curriculum teaches them exactly how to do this. Yet planning the use of time is instrumental in the art of teaching: planning the length and pace of lessons, the time used to grade students' work, and even planning a time to plan time.

Time for teachers can be described in two ways: didactic time, which is a linear, chronological framework for applying and evaluating lessons; and time capital, which is the objective value attached to a time-taking activity. Didactic time is what "regulates the activity of the teacher" and time capital is the 
worthiness of spending time on a particular pursuit (Assude, 2005, p. 185).

Research suggests that older adults, including older students, report more desire to pursue work-related activities and less desire to pursue sleep than younger adults, or younger students (Chen, Lee, Pethel, Gutowitz, \& Kirk, 2012). The desire to pursue work-related activities most likely translates to more time spent pursuing work-related activities. Nontraditional students who spend more time working on their student teaching, for example, might have better results and more impact on student learning than traditional students who perhaps spend less time on student-teaching activities.

Teacher Preparation at Illinois State University

Teacher preparation programs generate novice teachers, both traditional and nontraditional, so therefore these programs attend to both groups before they are novice teachers, at the student-teaching phase (Darling-Hammond \& Bransford, 2005). Preservice teachers seeking bachelor's degrees in teaching currently undertake the same curriculum and instruction regardless of their traditional/nontraditional status.

Specifically, ISU prepares about four hundred secondary preservice teachers each year. In 1997, the institution's Council for Teacher Education created the Realizing the Democratic Ideal as a conceptual framework for its teacher education programming. The framework concludes that "in order to have a truly democratic society, all individuals must have a voice and that education is the key to helping individuals develop their voices" (Illinois State University, 
2011). To that end, all curriculum and teacher preparation are guided by the principles within this framework.

At ISU, student teachers' culminating experiences are evaluated with a rubric based on the Realizing the Democratic Ideal (RDI). Evaluators use this rubric to rate a student teacher's overall performance in the classroom. This rubric is divided into three major categories: professional demeanor, interpersonal skills, and teaching and learning. Scores are given on a continuum from unacceptable, to satisfactory, to proficient, to exemplary, which is rarely seen in student teaching. The rubric also has descriptive paragraphs for each category and each scoring section (Appendix A). All student teachers must be rated with the same rubric, regardless of age or experience.

In order to produce graduates, or novice teachers, who are highly qualified to teach soon after graduation from teacher preparation programs, teacher preparation programs should address the needs that these differences in life experiences and age may require. Traditional preservice teachers (those who are in their first bachelor degree program just after finishing high school), particularly at the student-teaching stage, may require a different kind of guidance as compared to nontraditional preservice teachers at the studentteaching stage, but currently are not provided differentiated educational experiences.

$$
\text { Purpose of the Study }
$$

The purpose of this study was to determine whether secondary education teacher preparation programs should differentiate curriculum and instruction for 
traditional and nontraditional preservice teachers. Comparisons were made at the end of their student teaching, and were explored and defined in order to inform teacher educators as to possible programmatic changes to accommodate better the two groups in their teacher preparation and student-teaching experiences.

\section{Research Questions}

The following questions guided the research design, methodology, data collection, and data analysis for this study. The questions incorporated the dependent variables, which were the scores on the RDI Student Teaching Assessment (Appendix A) and the Preservice Teacher Perception Survey (Appendix B). Specifically, the scores were grouped by the constructs defined by the framework of the RDI Student Teaching Assessment, such as professional demeanor, teaching and learning, and interpersonal skills, and an additional construct, time management. The independent variables were the preservice teachers' status as either traditional or nontraditional. The independent variables were defined only by date of birth, not by high school graduation date.

1. How did traditional preservice student teachers differ from nontraditional preservice student teachers in terms of their scores on the professional demeanor construct of the RDI Student Teaching Assessment?

2. How did traditional preservice student teachers differ from nontraditional preservice student teachers in terms of their scores on 
the teaching and learning construct on the RDI Student Teaching Assessment?

3. How did traditional preservice student teachers differ from nontraditional preservice student teachers in terms of their scores on the interpersonal skills construct on the RDI Student Teaching Assessment?

4. How did traditional preservice student teachers differ from nontraditional preservice student teachers in terms of their scores on the time management construct on the Preservice Teacher Perception Survey?

5. How did traditional preservice student teachers compare to nontraditional preservice student teachers in terms of their rates of correlation between their perceptions of the constructs per their Preservice Teacher Perception Surveys and their actual assessed performance per their RDI Student Teaching Assessments?

6. How did both groups of preservice student teachers compare before their student teaching experience to after their student teaching experience?

\section{Hypotheses}

The following hypotheses informed the choice of one of the data collection instruments, the RDI Student Teaching Assessment, and the design of the other data collection instrument, the Preservice Teacher Perception Survey. The null hypothesis is a prediction of no difference between the two groups. 
1. There is no difference between the perceptions of predicted performance of traditional preservice student teachers and nontraditional preservice student teachers.

2. Both traditional preservice student teachers and nontraditional preservice student teachers will show the same amount of growth in a performance-based assessment from the beginning of their student teaching experience to the end of their student teaching experience.

These null hypotheses were the basis for future extrapolation of predictive preservice teacher performance. If the hypotheses proved not true, that could imply that teacher preparation programs do need to differentiate curriculum and instruction for the two different groups of preservice teachers. If the hypotheses proved null, then no changes would be indicated.

\section{Definitions}

For the purpose of this study, the following terms were used. The first two terms were defined from a compilation of several studies and reports, including from the Illinois State University Teacher Education Center as well as United States of America government reports.

1. Traditional preservice student teacher - a college student who has passed all relevant coursework, is in the final semester of teacher training, and entered the teacher education program immediately upon graduating from high school, and is in his/her early twenties (Paccion, McWhorter, \& Richburg, 2000, Lee \& Lamport, 2011, Advisory Committee on Student Financial Assistance, 2012). 
2. Nontraditional preservice student teacher - a college student who has passed all relevant coursework, is in the final semester of teacher training, and entered the teacher education program after first obtaining a different college degree or after spending more than one year in one or more careers other than teaching, and is older than early twenties (Paccion, McWhorter, \& Richburg, 2000, Lee \& Lamport, 2011, Advisory Committee on Student Financial Assistance, 2012).

3. Student teaching - the culminating field experience in which preservice teachers teach students under the supervision of cooperating classroom teachers and university supervisors. Student teaching is the capstone of the teacher education process and occurs after clinical experiences when all major course requirements have been met. During student teaching, students steadily increase classroom responsibilities and demonstrate competency in planning, assessment, instruction, and other professional tasks (Illinois State University College of Education Teacher Education Center, 2013).

4. Cooperating classroom teacher - a teacher who has enough experience teaching to be trusted to guide and assess a preservice teacher. Cooperating teachers play a vital role in the preparation of their future colleagues. They help to transition preservice teachers from students to professional adults. To be a cooperating teacher, Illinois School Code mandates that applicants be licensed and 
qualified to teach in the same area as the student teacher, have three years of teaching experience in a public school or an Illinois State Recognized nonpublic school, have received a proficient or above performance rating in their most recent evaluation, and are directly engaged in teaching subject matter or conducting learning activities in the area of student teaching (Illinois State University College of Education Teacher Education Center, 2013).

5. University supervisor - a university employee who is a liaison between the college and the high school in which the preservice teacher is student-teaching; will assess the preservice teacher. University supervisors act as the intermediary between the university and the host school to ensure the best environment for practice teaching (Illinois State University College of Education Teacher Education Center, 2013).

\section{Limitations of the Study}

This study was limited by its number of participants and by the characteristics of its participants. For the purposes of narrowing the data collection procedure, only secondary preservice teachers were studied; no elementary or special education preservice teachers were invited to participate. In addition, only preservice teachers at one university, Illinois State University, were invited to participate. 


\section{CHAPTER II}

\section{REVIEW OF LITERATURE}

The goal of teacher preparation programs is to create novice teachers who are highly qualified to teach. Teacher preparation programs enroll, generally, two types of students: the traditional student who enters college immediately after graduating from high school while in his or her late teenage years, and the nontraditional student who may already have a bachelor's degree or higher, may have already had a career different from teaching, and is already in his or her mid-twenties or later. Both of these types of students will eventually become preservice student teachers, and perhaps each type requires different treatment from teacher preparation programs leading up to and during the student teaching phase of their teacher preparation.

In order to create a study that compared the experience of traditional and nontraditional preservice teachers in teacher education programs, it is crucial to understand what previous research has discovered and illuminated. Concepts and topics that inform this study include research related to highly qualified teachers, novice teachers, teacher preparation programs, preservice teachers including traditional students and nontraditional students, cooperating teachers, university supervisors, field experiences, student-teaching experiences and time management. An exhaustive review of the literature follows which examines and 
connects those concepts and topics to this study, but reveals a dearth of information about traditional and nontraditional preservice teachers.

Highly Qualified Teachers

In January of 2002, in a strident effort to improve unilaterally all aspects of public education, then-President George W. Bush signed the "No Child Left Behind Act," also known as Public Law 107-110, which had several lofty goals. One such goal included teachers being "highly qualified." In the NCLB act, "highly qualified" is defined as a teacher who "has a bachelor's degree, meets full state licensure, and demonstrates subject area knowledge for each core subject" he or she teaches (No Child Left Behind Act of 2001, 2008). States vary in their licensure requirements for secondary teachers, with some states accepting teachers who majored in their subject area expertise, some states accepting teachers who minored in their subject area expertise, some states accepting teachers who both majored or minored and passed a subject area content exam, and some states accepting teachers who merely passed a subject area content exam (Brown, 2004).

In the State of Illinois, to qualify to teach Language Arts in a high school, teachers must have a major or minor in English or a related subject, pass a subject area content test administered by the State of Illinois, and pass an "Assessment of Professional Teaching" test (Illinois State Board of Education, 2013). The tests are pass/fail; a higher score on a test does not indicate a legitimate designation as a more highly qualified teacher (Pearson Education Inc., 2013). So as far as federal law is concerned, even novice teachers can be 
considered highly qualified teachers if they have achieved the basic requirements. There is no evidence to suggest that traditional preservice teachers should take a different test that nontraditional preservice teachers; it is assumed that all preservice teachers should be able to perform equally well on the test. Regardless of how "highly qualified" they may be according to state requirements, teachers with no classroom experience are novices.

\section{Novice Teachers}

Novice teachers are by definition new to the practice of teaching; they are not necessarily new to the practice of working for a living. Novice teachers who obtain their first teaching jobs in school districts that pay close attention to their attrition rates fare better than those who find themselves in districts that do not support novices enough through induction and mentoring programs. These districts are indeed very powerful in shaping teachers through the "tasks they assign, resources they provide, learning environments they create, assignments they design, and conversations they provide" (Grossman \& Thompson, 2004, p. 298). The research on these districts did not supply any information regarding the status, traditional or nontraditional, of the recent graduates who were hired to become novice teachers.

Another study examined novice teachers' performances in professional aspects. The participants, all novice teachers, wrote examples of dilemmas which most perplexed them in their teaching. These dilemmas seemed to indicate to the researchers that novice teachers are more likely than student teachers to utilize other school personnel to solve a problem. In addition, 
teachers needed more professional development to learn how to communicate well with parents and to educate teachers about "culturally relevant" classroom management techniques (Mastrilli \& Sardo-Brown, 2002, p. 61). There was no suggestion about the age of the novice teachers and whether they were traditional or nontraditional graduates of the teacher education programs.

The dispositions of preservice and novice teachers have also been examined as to who were more confident and competent and therefore more likely to motivate their students, have more impact on student achievement, and remain in the profession longer than teachers who were not confident and competent (Knobloch \& Whittington, 2002). While this study did describe older novice teachers in the demographics, it did not compare or contrast these teachers with younger novice teachers. Instead, all teachers were considered to be the same sample of the population.

In Schoolteacher: A Sociological Study (Lortie, 1975), a theme common through cases presented is that teachers teach how they were taught, thus continuing a cycle of teaching regardless of the possible theories that were taught to them during their teacher preparation. Preservice teachers glean more information from the manner in which they receive their teacher training than from the content of the teacher training. Two recent studies referred to this concept and point to a disconnect between the research-based theory that teacher candidates are learning in their teacher education coursework and the instinctive practice that they rely upon when they are actually teaching (Moore, 2003). Additionally, the researchers here called the easing into the first years of 
teaching "occupational socialization." Current school and student expectations contributed to the slow abandonment of preservice theoretical practice in favor of more teacher-directed and teacher-centered classroom activities. Cooperation and collaboration with colleagues also played a big part in whether these novice teachers continued to utilize their theoretical practice or shelved it in favor of "old school" principles (Brouwer \& Korthagen, 2005, p. 3). Noticeably missing is a direct comparison of the performance of the older novices, whose elementary and secondary educational preparation would be vastly different from the elementary and secondary educational preparation of younger novices.

The research on novice teachers shows that their success in their classrooms depends upon the support of their current employer, the awareness of the need both to ask questions and to grow professionally, and the foundation of student-teaching experience upon which they can build in their practice. The research also reveals that novice teachers are likely to ease away from the theoretical foundations provided by their teacher preparation schools and slip into teaching not only the way they themselves were taught, but also the way their more experienced colleagues are teaching.

However, there is no quantitative research to measure the degree of professional readiness and preparedness for novices based on their status as either traditional or nontraditional.

\section{Teacher Preparation Programs}

Common issues or struggles for novice teachers could indicate issues with their college teacher-training or some components of their teacher education 
preparation. "Colleges of education have increasingly become concerned about what constitutes compelling evidence that graduates indeed have a significant and positive impact on the achievement of their students" (Singer-Gabella, et al., 2007, p. 115). Preservice teachers' progress toward beginning teacher competence both before full-time teaching and after graduates began full-time teaching has been examined (Carpenter \& Lehrer, 1999). The researchers acknowledge the discrepancies that exist about what knowledge and skills beginning teachers should have, which of course would lead to the determination of what criteria a teacher preparatory curriculum should include.

\section{Teacher Preparation Curriculum}

For example, teacher educators emphasize knowledge of subject matter as well as pedagogical strategies for beginning teachers, while also fostering caring, committed, and autonomous decision-makers (Feiman-Nemser, 2001). But Singer-Gabella points out that recent federal regulations emphasize the delivery of content matter and the ability to manage a classroom. This dichotomy is also expressed by student teachers, whose questions and confidence evolved around whether they know enough of the content and can effectively manage the students.

Lee Shulman has long advocated three types of knowledge: subject matter, such as grammar or American literature; pedagogical knowledge, which is understanding how to explain and teach grammar or American literature so that someone else can learn it; and within the pedagogical knowledge, the most useful forms to present the ideas being taught and understood (Shulman, 1986). 
Another way to describe this is "school knowledge, which is the transposition from subject matter to pedagogical knowledge" (Banks, Leach, \& Moon, 2005, p. 335).

A summary of existing research on teacher preparation reveals that current studies seemed to indicate a necessary "pedagogical content knowledge" for teachers to be effective with their students. In fact, while future teachers have mastered the basics in their content area, they "lack the deeper conceptual understanding necessary when responding to student questions and extending lessons beyond the basics" (Wilson, Floden, \& Ferrini-Mundy, 2002, p. 192). No research "directly assesses what teachers learn in their pedagogical preparation and then evaluates the relationship of that pedagogical knowledge to student learning or teacher behavior" (p. 193). "Common sense decrees that both content knowledge and professional knowledge are essential to a teacher's education. What is not obvious is how we should conceptualize them, how we should help beginning teachers to acquire them, or what we should expect of beginning and more experienced teachers" (Sosniak, 1999, p. 196). Wilson, et. al. then looked at "What policies improve the quality of pre-service teacher education?" (p. 197). They found no rigorous studies that "focused directly on the relationship between policies and teacher preparation quality" (p. 198).

Preparing Teachers for a Changing World: What Teachers Should Learn and Be Able To Do, edited by Linda Darling-Hammond and John Bransford (2005), examines teacher preparatory curricula, with issues ranging from learning theories to developmentally appropriate goals to teaching subject matter, 
teaching to diverse learners, assessing student learning, managing the classroom, and implementing curriculum change in teacher education programs. One possible problem pointed out in this text is the manner and style in which courses are taught. Developmentally, college students might need more scaffolding with their education and content area classes in order to best access this information later when they are teaching in their own classrooms. So, just as teacher candidates are learning to "use children's experiences strategically in encouraging their further development," teacher educators should use preservice teachers' experiences strategically to encourage their further development (Horowitz, Darling-Hammond, Bransford, Comer, Rosebrock, \& Austin, 2005). This would require teacher educators to understand their learners and perhaps even to differentiate their instruction based upon their learners' status as traditional or nontraditional.

\section{Teacher Preparation Instruction}

How teacher preparation programs teach their students is as important as what they teach their students. The constructivist movement in education has been evolving since its inception by Jean Piaget in the middle of the twentieth century, and while educators for the most part agree that scaffolding and building upon prior knowledge is a good way to teach children, teacher educators do not use this concept when it comes to their own teaching of their students, preservice teachers. A study by Goubeaud and Yan (2004) reveals that while the authors admit that it remains unclear whether teacher educators' strategies, assessments, and grading methods impact student outcomes, they still claim that 
teacher candidates who learn in programs that incorporate constructivism into instruction will become teachers who incorporate constructivism into their own teaching. Darling-Hammond believes that "teachers need to understand subject matter in ways that allow them to organize it so that students can create useful cognitive maps of the terrain under study" (1999, p. 223). Further, "understanding subject matter in this way provides a foundation for pedagogical content knowledge, which enables teachers to represent ideas so that they are accessible to others" (1999, p. 224). Preservice teachers recognize these two different types of knowledge, and fear "they will never know enough to teach. Two fears are collapsed into one: knowing how to teach and knowing everything there is to know about the material" (Britzman, 2003). Griffin reports that "helping prospective teachers to think like teachers while also attending to what it is like to be a student with that teacher is difficult ...work for a teacher educator, but it should be the central focus of teacher education programs" (Griffin, 1999, p. 15).

Some teacher education programs are trying new approaches to clinical experience. "Campus-based teacher education has been criticized for its lack of a theoretical base, irrelevance to schools and children, superficial nature, and lack of unity and integration of campus and field... field experiences merely socialize the novice teachers in the existing school environment" (Byrd \& McIntyre, 1996, p. xiv). One such attempt paired preservice teachers together to team-teach in their student-teaching experiences. The researchers then followed these participants into their first teaching assignments to see what impact, if any, the peer-teaching experience had on their first year of teaching. Overall, the 
novice teachers perceived their peer student teaching as a valuable experience that prepared them well for their current jobs. The principals agreed with them, and found that these novice teachers had better interpersonal skills than most beginners, not only with their students but also with other faculty as well as parents. Next, the novice teachers were better able to reflect upon their teaching, receive and give feedback about teaching, and collaborate with other teachers (Birrell \& Bullough, 2005).

In addition, Massengill, Mahlios, and Barry (2005) examined teacher candidates' metaphors for themselves and how metaphors are related to how they acquire and come to know concepts. Interestingly, these five cases revealed that their metaphors for life, childhood, and teaching did not change over the two years of this study. Also interesting, in the interviews, the teachers realized that their own teaching failed to measure up to their idealized metaphors. The implications for this study are that teacher educators need to pay closer attention to these metaphors in order to scaffold new concepts about teaching to prior concepts.

Technology plays an ever increasing role in education, and teacher educators need to keep that in mind for their own classes. According to a study by Swain, preservice teachers have a good knowledge base of technology, particularly computers, and there is a significant need for teacher educators to build upon that knowledge base. Unfortunately, preservice teachers picture themselves using technology, but not in any innovative way other than the ways to which they have been exposed (Swain, 2006). 
To fully describe a concept, sometimes it is helpful to describe its opposite, or what it is not. In addition to learning how to teach, it is perhaps a good idea to know what it means to be a bad teacher. Another study claims that while there is a huge knowledge base for what defines and exemplifies good teaching, not a lot exists that defines bad teaching. Yet, sometimes it is helpful to know what not to do, in addition to knowing what to do. Such characteristics include "lacking subject knowledge, having poor classroom control, acting unprofessionally, the inability to diagnose learning problems, an obsession with method, focusing on the wrong goals or having no goals at all" (Foote, Vermette, Wisniewski, Agnello, \& Pagano, 2000, p. 129). Both student teachers and cooperating teachers should be aware of these characteristics and work toward avoiding the listed traits and habits. Such issues can apply to both traditional and nontraditional new teachers.

\section{Alternative Certification}

Alternative certification usually requires that its participants have already earned a bachelor's degree, which would imply that most, if not all, alternative certification students would be classified as "nontraditional." In the State of Illinois, those seeking alternative certification must "have graduated from an accredited college or university with a bachelor's degree, have passed the basic skills and subject matter tests, and successfully complete the first phase of the Alternative Certification program" which is "the course of study offered on an intensive basis in education theory, instructional methods, and practice teaching" (Illinois State Board of Education, 2012). While comparing traditional teacher 
education programs to alternative certification programs, one study discovered that the traditional teacher education programs prepare teachers much more thoroughly and effectively than the alternative certification programs. These findings are significant because they correlate strongly to "teachers' sense of efficacy and their confidence about their ability to achieve teaching goals." In addition, accreditation used for quality control has improved teacher education programs and therefore the teachers they produce (Darling-Hammond, Chung, \& Frelow, 2002, p. 296). In fact, Illinois State University no longer offers an Alternative Certification program. Regardless of baccalaureate degree or only certification, teacher education programs share a common goal, that of preparing future teachers.

\section{Preservice Teachers}

Preservice teachers have completed their classroom coursework and are ready for their student teaching. The student-teaching experience is a culmination and application of the concepts studied in content-area classes and education classes including theories of teaching and learning, pedagogical concepts, and methodology. Preservice teachers also worry about themselves. "They often believe that teaching is merely transmitting information and enthusiastically encouraging students, rather than assess student learning to guide purposefully organized learning experiences with carefully staged supports" (The National Academy of Education, Committee on Teacher Education, 2005, p. 33). Preservice teachers are comprised of mainly two types of students: traditional and nontraditional. 


\section{Traditional Students}

For the purposes of this study, the term "traditional" indicates the preservice teacher who entered the university immediately upon graduating from high school and is at the time of student teaching approximately between twentyone and twenty three years of age. For most reports, the definition of "traditional" is implied as being the opposite of "nontraditional," and the term "nontraditional" is explicitly detailed. Traditional is seen as "recent high school graduates" while nontraditional is "students who tended to delay entry to college from high school" (Advisory Committee on Student Financial Assistance, 2012, p.2).

On Knowles's continuum of learner characteristics, traditional students would tend more toward the "teacher-directed" side than the "learner-directed" side. Instructors of traditional students tend to use more pedagogy than andragogy (Merriam, 2001, p. 6).

The current literature, such as a textbook for nursing instructors, Nursing Education: Foundations for Practice Excellence, (Moyer \& Wittmann-Price, 2008), refers to the "millennial" student, born after 1980. Such learners are "optimistic, cooperative team players who accept authority and follow rules; are smarter than most people think and believe in the future and see themselves as its cutting edge" (Howe \& Strauss, 2000, p. 7). Millennials are "techno-savvy, adept at global and diversity issues, team-oriented, multi-taskers....who lack discretion, independence, realistic expectations, patience, work ethics, and soft skills and the basics, such as grammar" (Tyler, 2007, p. 42). Another interesting find is that for millennials, "computers aren't technology, it is an assumed way of 
life; doing is more important than knowing, and multi-tasking is a way of life" (Oblinger, 2003, p. 40).

Millennials are considered "digital natives." "These individuals have spent their entire lives immersed in a digital culture, to the extent that it has fundamentally changed the way in which they process information; so much so, they possess distinct learning styles and preferences never before seen" (Nasah, et. al., n.d., p. 532; Prensky, M. 2001).

Teacher educators must be able to understand millennials in order to get millennials to understand the art and science of teaching while negotiating dependably in the student-teaching setting. In light of their presumed relative immaturity, traditional preservice teachers may have a tendency to be more willing to claim credit for their successful experiences than they were to accept responsibility for their unsuccessful experiences (Killen, 1994). These students perhaps work differently with their educators and mentors compared to nontraditional students.

\section{Nontraditional Students}

For the purpose of this study, the term "nontraditional" indicates the preservice teacher who is in a second bachelor's program after completing a first bachelor's in an area other than education, or has served in the Armed Forces between high school graduation and university, or has had at least one different career and has entered the university to obtain a degree in education. These students are also known as "career switchers" or "career changers," and many of them have multiple roles including spouse, parent, and employee. 
The counterpart to the millennial learner is the adult learner, who is more "self-directed, possessing years of experience and a wealth of information, being internally or intrinsically motivated; approaching learning with a desire to apply information to solve problems, and relating new knowledge to previously learned information and experiences" (Baumlein, 2004. p. 435). In addition, "years of employment in the content areas allow [non-traditional teacher candidates] to integrate school-to-work principles and practices into their content area specializations...making the curriculum relevant and meaningful for secondary students" (Paccion, McWhorter, \& Richburg, 2000).

On Knowles's continuum of learner characteristics, nontraditional students would tend more toward the "learner-directed" side than the "teacher-directed" side. Instructors of nontraditional students tend to use more andragogy than pedagogy (Merriam, 2001, p. 6). These students would also be considered "digital immigrants," as they have not spent their lives immersed in a digital culture.

In 2007, adult learners who were age twenty-four or older "currently comprise about 44 percent of U. S. postsecondary students" (Kazis, Callahan, \& Davidson, 2007, p. 2).

A recent study of 95 college students, 58 traditional and 27 nontraditional, found that while both groups self-reported similar levels of motivation and study behaviors, nontraditional students used higher cognitive strategies. This led the researchers to declare that for nontraditional students, "the ability to provide appropriate academic experiences will depend on an understanding of the 
factors that affect their learning" (Justice \& Dornan, 2001, p. 248). As for nontraditional preservice teachers, "There is a need for more research on this population of non-traditional entrants to the teaching profession, especially those who have had prior professional careers" (Lee \& Lamport, 2011, p. 1).

Some research suggests that nontraditional preservice teachers, while possessing skills acquired in other careers and/or having experience with raising children, could feel inadequately prepared to student teach. They are perhaps accustomed to complete autonomy and one-on-one working relationships with adults, which renders them unsuited to deal with school bureaucracy and the challenges of handling twenty or more students in a room at a time (Novak \& Knowles, 1992).

Lee and Lamport suggest that teacher educators offer realistic programs and problem-solving coursework to accommodate nontraditional preservice teachers and better prepare them for their student teaching and beyond (Lee \& Lamport, 2011). While those descriptions aid instructors in understanding their learners, they do not extend so far as to inform how the learners will respond after the content and pedagogy classes have taken place and the studentteaching experience is their current challenge.

A case study of four "career-switcher" novice teachers, (those who had previously had a different career from teaching) using analyzed journals, guided discussions, various kinds of input from mentors, supervisors' evaluations, selfevaluations, and researchers' observations, found that the novice teachers had more trouble balancing teaching, family, and outside obligations than they had 
anticipated. Not many demographic details were revealed in the study, so it is unknown whether the career-switchers (who would be considered nontraditional by the definitions in this study) had spouses or families (Wilcox \& Samaras, 2009).

\section{Student Teachers}

Regardless of traditional or nontraditional status, preservice teachers take the same required classes. All the preparation of the classes may not apply directly to how preservice teachers rate their own performances in student teaching. A study of nineteen language arts student teachers, both traditional and nontraditional, found that "the four factors most affecting their feeling of success were learning, relationships, confidence and respect." In addition, "they defined 'success in student teaching' in terms of student learning, their own learning, positive relationships with other adults in the context, especially cooperating teachers; feedback from students and cooperating teachers; feeling respected in the teacher role; and confidence that they know what they are doing" (Wilson C. L., 2000, p. 218).

Many student teachers worry about developing classroom management techniques. "Implicitly, both teachers and students understand two rules governing the cultural tensions of life in compulsory education: unless the teacher establishes control, there will be no learning; and, if the teacher does not control the students, the students will control the teacher" (Britzman, 2003, p. 224). Student teachers get to practice and hone their classroom management skills when student learning really counts, the student-teaching phase of teacher 
education. These studies uncover important aspects of student teachers and their experiences, but they do not illuminate any differences between traditional and nontraditional preservice teachers and their perceptions. And neither study examined the cooperating teachers' perspectives of traditional and nontraditional preservice student teachers.

\section{Cooperating Teachers}

A cooperating teacher is one who has been teaching long enough to be entrusted with guiding a preservice teacher through a field experience. The cooperating teacher allows a preservice teacher to practice teaching in his/her classroom but is ultimately responsible for the learning his/her students achieve. Thus, the stakes are high for the cooperating teacher, just as they are for the preservice teacher. A cooperating teacher is expected to be a guide, helper, listener, role model, instructor of classroom management, friend, and academic example (Rajuan, Beijaard, \& Verloop, 2007, p. 141).

More than merely "transferring authority to the student teacher," a good cooperating teacher must also be transparent about decision-making and planning so that preservice teachers have a better grasp of how to think and act while practicing in the classroom (Feiman-Nemser \& Beasley, 2007).

Furthermore, "superior teachers make decisions about the instructional process, including what to teach and what questions to ask. It is the distinction between 'know how' and 'know why' that separates the professional educator from the novice teacher" (Henry \& Weber, 2010, p. 8).The cooperating teacher will 
evaluate the preservice teacher's performance in the classroom, along with the other third of the student-teaching triad, the university supervisor.

\section{University Supervisors}

The university supervisor can be a professor, a graduate student, or a university employee charged with ultimately grading the preservice teacher's teaching performance and therefore allowing the preservice teacher to pass or fail the student teaching course. The duties of the supervisor include observing the preservice teacher's lessons; reviewing the preservice teacher's responsibilities, requirements, and time lines; evaluating lesson plans; providing a direct link to the university; providing support to the cooperating teacher; and determining instructional and management styles of cooperating teachers to serve preservice teachers (Enz, Freeman, \& Wallin, 1996). University supervisors link the teacher education and preparation program to the practice teaching.

\section{Field Experiences}

Prior to the student teaching experience, teacher preparation programs require extensive hours of observation and discussion in actual secondary school settings with actual high school students. At Illinois State University, preservice teachers who are not yet student teaching need to spend 20-30 hours observing in and outside of their discipline, 3 hours of teaching, 12 hours of planning, 5 hours of aiding teachers, and 5-10 hours conferencing with their cooperating teacher. This takes place at University High School in Normal, Illinois; it is considered a laboratory school and its faculty works closely with the teacher 
education faculty to better teach and serve both college students and high school students. A recent study of these preservice teachers found that their cooperating teachers rated them highly in regard to their professionalism, interactions with their high school students, and rapport with the cooperating teachers themselves, but that they needed better preparation in classroom management (Al-Bataineh, 2009). This study yielded no discussion about the status of the preservice teachers as either traditional or nontraditional.

\section{Student Teaching}

Also known as a clinical experience or a field experience, student teaching is the hallmark of most teacher education programs. To participate, preservice teachers will have completed their coursework, passed any applicable competency exams, and successfully navigated the various gate-keeping requirements demanded of their universities and state laws. At Illinois State University, secondary education majors undergo a sixteen-week student teaching experience (Student teaching for secondary and K-12 majors, 2011). Preservice teachers gradually increase their responsibility for student learning throughout the experience, with the guidance of their cooperating teacher and university supervisor. The evaluation form that is completed by both the university supervisor and the cooperating teacher is the defining factor whether the student teacher passes the student-teaching course and thus can go on to being certified as a teacher, or doesn't pass the student-teaching course and therefore must look to another option. Both traditional and nontraditional student teachers are held to the same standard and evaluated in the same way. 
It is argued that student-teaching experience cannot possible fully prepare preservice teachers to become perfect practicing teachers. "Preservice training is not designed to warn prospective teachers of all they might encounter. It's meant to lay a foundation for a reflective educator to build on or reference from time to time. Student teaching is an invaluable step to becoming a real teacher, but it can't anticipate all one will need to know" (Pauly, 2002, p. 286). While the student teaching experience is itself a frame of reference, the life experiences each student teacher brings to it will impact his or her response, reaction, and reflection.

\section{Time Management Theory}

Using time wisely as both a student and as a student teacher is both important and not explicitly taught by teacher preparation programs. Although students are expected over the course of their time in college to plan for their time and get assignments turned in for grading on time, no required class in the curriculum teaches them exactly how to do this. Yet planning the use of time is instrumental in the art of teaching: planning the length and pace of lessons, the time used to grade students' work, and even planning a time to plan time. Time for teachers can be described in two ways: didactic time, which is a linear, chronological framework for applying and evaluating lessons; and time capital, which is the objective value attached to a time-taking activity. Didactic time is what "regulates the activity of the teacher" and time capital is the worthiness of spending time on a particular pursuit (Assude, 2005, p. 185). 
Research suggests that older adults, including older students, report more desire to pursue work-related activities and less desire to pursue sleep than younger adults, or younger students (Chen, Lee, Pethel, Gutowitz, \& Kirk, 2012). The desire to pursue work-related activities most likely translates to more time spent pursuing work-related activities. Nontraditional students who spend more time working on their student teaching might have better results and more impact on student learning than traditional students who perhaps spend less time on their student-teaching activities.

\section{Conclusion}

The review of the literature reveals that while many teacher education programs are adopting best practices in their program design, field and clinical experiences, and teacher competency exams, the information on how preservice teachers are taught and whether traditional and nontraditional preservice teachers require the same approaches from teacher educators reflects a lot of inconsistency. Teacher educators teach their students, who are future teachers, to know their learners and know what their learners know and build or scaffold upon that knowledge.

The preservice teacher population is currently comprised of more nontraditional students than ever before, and nontraditional students have different prior knowledge than traditional students. Teacher educators may have to apply that concept of scaffolding to their preservice teachers and may have to discover more about the needs of preservice teachers in order to develop the 
most truly highly qualified novice teachers possible. Teacher educators may need to differentiate instruction based upon the needs of their own learners. 


\section{CHAPTER III METHODOLOGY AND PROCEDURES}

This chapter provides information about the methodology used in this study. The purpose of this study was to determine whether Illinois State University's secondary education teacher preparation program should differentiate instruction for its two groups of students, traditional and nontraditional, based on four constructs of professional demeanor, interpersonal skills, teaching and learning, and time management. Topics in this chapter include the research design, participants, variables, instruments, and statistical procedures.

\section{Research Design}

This study incorporated a quasi-experimental design because two existing groups were compared and therefore the population cannot be randomized (Creswell, 2005). The two groups were comprised of traditional preservice student teachers and nontraditional preservice student teachers.

The possible subjects were invited to participate. First they responded to a presurvey, given at the beginning of the student-teaching semester. Then, they were invited to respond to a postsurvey, given at the end of the student-teaching semester. After that, they were asked to grant permission for the researcher to obtain their scores from their RDI Student Teaching Assessment. 
For this study, quantitative methods provided the data, specifically evaluations from two general groups: preservice teachers and the team of cooperating teachers and university supervisors. The results from the instruments were compared in several ways. First, each Preservice Teacher Perception presurvey was compared to its correlating Preservice Teacher Perception postsurvey, item by item. Then, the items in each respondent's postsurvey was compared to the correlating items in the respondent's RDI Student Teaching Assessment filled out by both cooperating teacher and supervising teacher. This helped to measure the accuracy with which the preservice teachers judge themselves. Each variable was compared within the four constructs of professional demeanor, interpersonal skills, teaching and learning, and time management. Finally, the traditional preservice teacher group was compared to the nontraditional preservice teacher group to reveal any differences in either internal perceptions or external evaluations, using means and t-tests.

\section{Participants}

\section{Subjects}

Two groups were invited to participate in this study. Both groups were enrolled in the secondary education program at Illinois State University. One group, traditional student teachers, was comprised of those who attended a college immediately upon graduating high school. They may have attended a community college before transferring to ISU, or they may have attended a different university before transferring to ISU. Regardless, they were enrolled in 
some type of college since high school, without taking any time off. They also completed their college degree in four consecutive years, determined using birth dates. Birthdates from autumn 1990 and later placed participants into the "traditional student teacher" category.

The second group, nontraditional students, includes students with birthdates prior to summer 1990 . These students did not immediately enroll at ISU upon high school graduation. This group of nontraditional students might include veterans of the Armed Forces, career switchers, or perhaps parents who now have time to concentrate on getting their own education. In order to obtain birthdates a general overview of the study sample's demographic characteristics, variables such as gender and major were also included.

Human Subjects' Consideration

Permission to contact participants was obtained through the Illinois State University Institutional Review Board (IRB) Office. The data was labeled "confidential," as subjects were identified in order to match surveys to evaluations, but their identities were kept secret. Risks were disclosed as minimal and unlikely, but subjects might have felt anxious about questions regarding their student teaching performance. Possible benefits to the participants included time and method with which to reflect upon their studentteaching experience, as reflective activities have been known to prompt more thoughtful, deliberate actions, which could possibly have improved participants' student teaching. 
A copy of the informed consent letter is attached with the survey

(Appendix B.) The protocol number granted by the IRB is 2012-0122.

Modifications were granted in December 2012 in order to change the name of the primary investigator and to obtain spring 2013 participants' ULIDs (University

Logon Identification, also known as email addresses) for request for participation in the study.

\section{Sample Selection}

To obtain potential participants, the researcher asked the ISU College of Education Assistant Director of Certification and Data to provide ULIDs of the preservice teachers. A request for participation was sent via ISU email to the preservice teacher population, of whom there were 292 actively student teaching. Of the 292 preservice teachers, 168 were considered nontraditional preservice teachers, with 124 traditional preservice teachers. This assumes that the 168 started kindergarten at the age of five and did not repeat any grades.

Within the nontraditional group, 103 preservice teachers had birthdates from the summer of 1990 to the autumn of 1989. This group could have been placed in kindergarten a year later than the usual age five, or could have been held back a year in school, or could have taken longer than four years to graduate from college with a bachelor's degree. However, for the purpose of this study, the 103 in this gray area are still older and are presumed to be more mature and have more life experiences than the traditional group whose birthdates are autumn 1990 and earlier. 
Power Analysis

For a valid study, four factors must be considered: significance level, statistical power, analysis strategy, and effect size (Olejnik, 1984). This study, like most social science studies, utilized a .05 level of significance in order to avoid committing a Type I error of concluding that a relationship exists between variables when it does not. To avoid the error of not observing a relationship that does in fact exist, statistical power must be considered (Vogt, 2007). Obviously, for more statistical power, more subjects would be required. However, this study was limited to 292 total participants, of whom 168 are nontraditional. In addition, it was a voluntary study, and only 43 of the 292 total population, or $15 \%$, participated in answering the presurvey.

The statistical analysis strategy compared two groups based on just one independent variable, that of traditional or nontraditional status. This requires fewer subjects than if more independent variables were compared, or if it were a qualitative design (Olejnik, 1984). Finally, the last consideration was effect size, or how many should be included in the sample to ensure that the degree to which the null hypothesis can be determined false is small. However, "the exact answer to the sample size question can be given only when the specific parameters of the problem are provided and power curve such as those provided in advanced statistics textbook or sample size tables are consulted" (Olejnik, 1984, p. 44). While there is no exact "n" for a perfect sample size, it is reasonable to expect a bigger sample would be a better predictor of overall population. 
The timing of the survey was crucial here, because the data was captured toward the end of the student teaching experience in order to allow the respondents to be able to reflect upon more time spent student teaching. However, it was assumed that they had not yet had their final evaluation, so they did not yet know what their rating was. This is important because perhaps if some potential respondents had low evaluations, they would not want to expose them to a researcher.

\section{Participation Rate}

The presurvey was emailed to all 292 active student teachers in January, 2013. A reminder was sent to them ten days later. Only 43 of the $292(15 \%)$ provided valid responses to the survey. It is unclear whether the low response rate was due to computer problems, inability to find time to complete the fiveminute survey, or apathy, or any and all of the above. Of those 43 who responded, 23 were in the "traditional" student teacher category and 20 were in the "nontraditional" student teacher category.

In April 2013, the original participants received an email inviting them to respond to a postsurvey that was nearly identical to the presurvey they had already answered. Of those original 43 who responded to the presurvey, only 22 (51\%) responded to the postsurvey. Of the 22 who responded to the postsurvey, 15 were traditional and seven were nontraditional. Finally, of the 22 who answered both the presurvey and the postsurvey, only 14 (64\%) gave permission for the researcher to collect data from their student teaching evaluations, the RDI 
Student Teaching Assessment. Of those 14, 10 were traditional and four were nontraditional.

\section{Variables}

In this study, the independent variables were the status of the participants, either traditional or nontraditional. To measure differences between the two groups, four dependent variables were used. These variables were professional demeanor, teaching and learning, interpersonal skills, and time management. These dependent variables were chosen because all of the participants culminate their teacher education experience with one evaluative tool, the Realizing the Democratic Ideal (RDI) Student Teaching Assessment.

The constructs of professional demeanor, teaching and learning, and interpersonal skills are provided by the basis of the RDI Student Teaching Assessment. Realizing the Democratic Ideal was designed in 1997 by the Council for Teacher Education as the conceptual framework for all forty of its teacher education programs in five colleges (Illinois State University, 2011). The RDI Student Teaching Assessment uses the components professional demeanor, teaching and learning, and interpersonal skills as categories for evaluating student teachers (Appendix A).

According to the ISU College of Education's Assistant Director of Certification and Data, "The National Council for Accreditation of Teacher Education (NCATE) mandated in 2000 that teacher education programs needed to derive unit standards from conceptual framework and assess these standards" (L. A. Steffen, personal communication, August 7, 2013). This assessment has 
been designed and revised by the teacher education professors at Illinois State University and has been in use since the fall semester of 2002.

The assessment utilizes a rubric design which guides the evaluators, who are university supervisors and cooperating teachers, in rating preservice student teachers. The scores on the rubric range from 1 (unacceptable) to 2 (satisfactory...novice teacher) to 3 (proficient...novice teacher) to 4 (exemplary...experienced teacher, rare to be seen in student teaching) (Appendix A). It includes fifteen questions, of which only thirteen will be used in order to simplify the survey, thereby rendering it easier for student teachers to complete. Because the majority of the Preservice Teacher Perception Survey questions originated from the RDI Student Teaching Assessment, two items were eliminated to streamline the survey.

The last variable, time management, is not included in the RDI Student Teaching Assessment but it is included in the Preservice Teacher Perception Survey (Appendix B). This construct is a hallmark of nontraditional students, as they may be more likely to manage their time better and more constructively than traditional students.

The dependent variables for this study were the scores from the specific questions delineated above on the RDI Student Teaching Assessment at the end of student teaching, and the Preservice Teacher Perception Survey, at both prestudent teaching and post-student teaching points. These variables were further analyzed by comparing the scores on the specific questions. 


\section{Instruments}

RDI Student Teaching Assessment

The instruments that were used in this study include the RDI Student Teaching Assessment. It was included because it is an assessment used to rate all Illinois State University secondary preservice teachers at the end of the student-teaching semester, regardless of major. Cooperating teachers and university supervisors work together to assess the performance of each preservice teacher.

Professional demeanor is rated in questions one, two, and three of the RDI Student Teaching Assessment. These questions examine specialized content knowledge for teaching, communicating effectively, and using effective classroom management skills.

Table 1

Professional Demeanor Constructs on the RDI Student Teaching Assessment

\begin{tabular}{ll}
\hline \multicolumn{1}{c}{ Variable } & \multicolumn{1}{c}{ Description } \\
\hline Professional Demeanor 1 & Demonstrates specialized content \\
& knowledge for teaching. \\
Professional Demeanor 2 & Communicates effectively (written, verbal, \\
& and nonverbal). \\
Professional Demeanor 3 & Uses effective classroom management skills \\
& to maintain safe and positive learning \\
& environments.
\end{tabular}


Questions four and five, which examine demonstrating professional practice consistent with an appropriate philosophy of education and seeking appropriate opportunities for professional development, were omitted from this study in order to streamline the survey. These two questions were selected because they are less observable and more esoteric than the other questions.

Teaching and learning is rated in questions six through twelve of the RDI Student Teaching Assessment. These questions examine planning and developing lessons to meet instructional goals and serve diverse learners, differentiating instruction, appropriately integrating instructional resources, using multiple assessment strategies, using reflection to improve instruction, demonstrating persistence in helping all students learn, and using assessment to demonstrate positive impact on student learning.

Table 2

Teaching and Learning Constructs on the RDI Student Teaching Assessment

\begin{tabular}{ll}
\hline \multicolumn{1}{c}{ Variable } & \multicolumn{1}{c}{ Description } \\
\hline Teaching and Learning 1 & Plans and develops lessons to meet \\
& instructional goals and serve diverse learners. \\
Teaching and Learning 2 & Differentiates instruction. \\
Teaching and Learning 3 & Appropriately integrates instructional \\
& resources, including technology, into the \\
& curriculum to support student learning. \\
Teaching and Learning 4 & Uses multiple assessment strategies. \\
Teaching and Learning 5 & Uses reflection to improve instruction.
\end{tabular}


Teaching and Learning 6

Teaching and Learning 7
Demonstrates persistence in helping all students learn.

Uses assessment to demonstrate positive impact on student learning.

Interpersonal skills are evaluated in questions thirteen, fourteen, and fifteen in the RDI Student Teaching Assessment. These questions examine whether the student teacher demonstrates respect for all students, develops positive working relationships with others involved in the educational setting, and includes families in the education process.

Table 3

Interpersonal Skills Constructs on RDI Student Teaching Assessment

\begin{tabular}{ll}
\hline \multicolumn{1}{c}{ Variable } & \multicolumn{1}{c}{ Description } \\
\hline Interpersonal Skills 1 & Demonstrates respect for all students. \\
Interpersonal Skills 2 & Develops positive working relationships with \\
& others involved in the educational setting. \\
Interpersonal Skills 3 & Includes families in the education process. \\
\hline
\end{tabular}

\section{Preservice Teacher Perception Survey}

The other instrument that was used in this study is the Preservice Teacher Perception Survey, designed by the researcher. Its basis is the RDI Student Teaching Assessment with additional questions that exemplify in concrete terms some of the concepts of the assessment. These questions ask 
survey participants to rate their predictions of their student-teaching performance, using a Likert-type scale. Scores range from 1 (strongly disagree) to 2 (disagree) to 3 (agree) and to 4 (strongly agree).

To encourage participants to respond more thoughtfully to the survey, some questions were included which require almost opposite answers. For example, in the professional demeanor section, one question reads, "I can't wait to get my own classroom so I can teach my way," while another question is "I am apprehensive about being in my own classroom." These seemingly opposite questions are meant to inspire respondents to choose different values for their answers (Creswell, 2005).

The questions on the survey were in the same order as the items on the RDI Student Teaching Assessment, for both the presurvey and the postsurvey. The survey was designed to be administered at the beginning of the studentteaching experience, as a presurvey, and again at the end of the studentteaching experience, as a postsurvey. Accordingly, the presurvey consisted of future verb tense, such as "I will demonstrate" and "I will create," while the postsurvey used past verb tense, such as "I demonstrated" and "I created." To simplify, only the postsurvey descriptors with past verb tense are included in the tables below. 
Table 4

Professional Demeanor Constructs on the Preservice Teacher Perception Survey

\begin{tabular}{ll}
\hline \multicolumn{1}{c}{ Variable } & \\
\hline Professional Demeanor 1 & I demonstrated specialized content knowledge \\
& for teaching. \\
Professional Demeanor 2 & I communicated effectively (written, verbal, \\
& nonverbal). \\
Professional Demeanor 3 & I used effective classroom management skills \\
& to maintain safe and positive learning \\
Researcher Question & environments. \\
I felt like a "real teacher" during my student \\
Researcher Question & teaching. \\
I can't wait to get my own classroom so I can \\
teach my way. \\
I am apprehensive about being in my own \\
classroom.
\end{tabular}

The survey questions for the construct teaching and learning had a similar format, with similar extra questions to encourage thoughtful responses and gain more information about what preservice teachers thought about what might happen in their student teaching. 
Table 5

Teaching and Learning Constructs on the Preservice Teacher Perception Survey

\begin{tabular}{|c|c|}
\hline Variable & Description \\
\hline Teaching and Learning 1 & $\begin{array}{l}\text { I planned and developed lessons to meet } \\
\text { instructional goals and serve diverse learners. }\end{array}$ \\
\hline Teaching and Learning 2 & I differentiated instruction. \\
\hline Teaching and Learning 3 & $\begin{array}{l}\text { I appropriately integrated instructional } \\
\text { resources, including technology, into the } \\
\text { curriculum to support student learning. }\end{array}$ \\
\hline Teaching and Learning 4 & I used multiple assessment strategies. \\
\hline Teaching and Learning 5 & I used reflection to improve instruction. \\
\hline Teaching and Learning 6 & $\begin{array}{l}\text { I demonstrated persistence in helping all } \\
\text { students learn. }\end{array}$ \\
\hline Teaching and Learning 7 & $\begin{array}{l}\text { I demonstrated a positive impact on student } \\
\text { learning. }\end{array}$ \\
\hline Researcher Question & I created my own lessons. \\
\hline Researcher Question & $\begin{array}{l}\text { I used someone else's lessons but reworked } \\
\text { them to fit my needs. }\end{array}$ \\
\hline Researcher Question & I used someone else's lessons as they were. \\
\hline
\end{tabular}

The survey questions for the construct interpersonal skills, likewise, incorporated similar extra questions to encourage thoughtful responses and gain 
more information about what preservice teachers predicted their performance in the classroom.

Table 6

Interpersonal Skills Constructs on the Preservice Teacher Perception Survey

\begin{tabular}{ll}
\hline \multicolumn{1}{c}{ Variable } & \multicolumn{1}{c}{ Description } \\
\hline Interpersonal Skills 1 & I demonstrated respect for all students. \\
Interpersonal Skills 2 & I developed positive working relationships with \\
& others involved in the educational setting. \\
Interpersonal Skills 3 & I included families in the education process. \\
Researcher Question & I found it difficult to fit in with other teachers. \\
Researcher Question & I found it easy to work with other teachers. \\
Researcher Question & My cooperating teacher helped me \\
& immensely. \\
\hline
\end{tabular}

In addition, a section on time management was included, based on research which indicates that nontraditional students utilize their time better than traditional students do. Time management in this study refers to the preservice teacher's ability to effectively plan for and use time wisely in order to accomplish necessary tasks, accommodate unexpected events, and maintain balance in a student teacher's academic and personal life.

The survey was designed to capture an estimation of time spent on various student teaching tasks. The first two questions utilized the same Likert scale as the rest of the survey and asked participants to predict their ability to 
manage their time both at school and outside school, and to gauge the number of hours they spent planning their instruction, assessing student progress, and performing other educational tasks related to student teaching. The last three items asked participants to fill in the number of hours in response to the question.

Table 7

Time Management Constructs on the Preservice Teacher Perception Survey

\begin{tabular}{ll}
\hline \multicolumn{1}{c}{ Variable } & \multicolumn{1}{c}{ Description } \\
\hline Time Management 1 & $\begin{array}{l}\text { I was able to manage my time at the school } \\
\text { effectively. }\end{array}$ \\
Time Management 2 & I was about to manage my time outside the \\
school effectively. & Hours outside school spent planning \\
Time Management 3 & instruction per week (fill in number). \\
Time Management 4 & Hours outside school spent assessing student \\
& progress per week (fill in number). \\
Time Management 5 & Hours spent outside school performing other \\
& educational tasks related to student-teaching \\
& (fill in number).
\end{tabular}

\section{Validity and Reliability}

To ensure instrument validity, the proposed survey was based upon an approved evaluative tool already in use at ISU (L. A. Steffen, personal communication, August 7, 2013). Since the RDI Student Teaching Assessment 
was developed and is used by ISU as a student teaching gateway criterion, this instrument is valid both in content and criterion according to the standards of the RDI. ISU is accredited by the National Council for Accreditation of Teacher Education, and so meets rigorous standards by using accepted assessment procedures. The Preservice Teacher Perception Survey was built around the concepts in the RDI Student Teaching Assessment, particularly the categories of professional demeanor, teaching and learning, and interpersonal skills. The scores from this study will be used only with each other, not with any other scores in any other study, which lends to its construct validity (Creswell, 2005; Vogt, 2007). Respondents' answers to the surveys will be paired only with their own corresponding answers and evaluations.

This survey was piloted in a basic form in the spring of 2012. It was administered only at the end of the student teaching semester. It required participants to answer 10 demographic questions in addition to the questions regarding the four variables. Based on the low response rate, the demographic questions were eliminated and the researcher obtained permission from the Institutional Review Board to acquire certain demographic details via the Illinois State University mainframe. These demographic details include major and birth date. The piloted survey also prompted a change to the research design to incorporate a presurvey, in order to capture a measurement of growth of preservice teachers' perceptions from the beginning of the semester to the end of the semester. 
The survey was available online through the Select Survey website, for which ISU provides support to its users. The Preservice Teacher Perception Survey was given to respondents twice. The first time, it was offered through an invitational email from the researcher to all 292 preservice teachers at the beginning of the semester, January 2013. At the end of the semester, April 2013, it was sent online to the actual respondents only; only preservice teachers who responded to the presurvey were invited to participate in the postsurvey. These surveys were identical except for verb tense. The presurvey used future verb tense to indicate anticipatory responses, and the postsurvey used past tense to indicate reflective responses.

\section{Statistical Procedure}

All online survey scores and evaluation scores were entered into an Excel spreadsheet. First all the scores from the participants' presurveys were put into an Excel spreadsheet, and then all the scores from the participants' postsurveys. Finally the scores from the RDI Student Teaching Assessment were entered into the spreadsheet.

The presurvey questions were compared, item by item, to the postsurvey questions using a simple subtraction formula to get differences between each individual participant's answers on the postsurvey and on the presurvey. Then means were calculated for each group, traditional and nontraditional, based on each individual item. For example, Participant 1001's answer to the presurvey question one in the Professional Demeanor category was subtracted by the answer to the postsurvey question one in the Professional Demeanor category; 
then all of the traditional participants' answers to the presurvey question one in the Professional Demeanor category were averaged, as were all of the nontraditional participants' answers.

After the averages were computed, Excel ran a two-sample two-tailed ttest. This statistical test was chosen because the focus was on the difference between participants' scores on the presurvey and on the postsurvey; participants were surveyed more than once; there are two groups, traditional and nontraditional. This leads to the t-test for dependent means. A two-tailed t-test was chosen rather than a one-tailed t-test because the distribution of the scores could go in either direction of a typical bell curve (Salkind, 2004).

To analyze the data, the scores were compared within each of the four constructs: professional demeanor, teaching and learning, interpersonal skills, and time management. A group means was calculated, for each group, traditional and nontraditional. The data was organized by with its corresponding research question.

1. How did traditional preservice student teachers differ from nontraditional preservice student teachers in terms of their scores on the professional demeanor construct of the RDI Student Teaching Assessment?

Scores were averaged to compare the traditional and nontraditional groups.

2. How did traditional preservice student teachers differ from nontraditional preservice student teachers in terms of their scores on 
the teaching and learning construct on the RDI Student Teaching Assessment?

Scores were averaged to compare the traditional and nontraditional groups.

3. How did traditional preservice student teachers differ from nontraditional preservice student teachers in terms of their scores on the interpersonal skills construct on the RDI Student Teaching Assessment?

Scores were averaged to compare the traditional and nontraditional groups.

4. How did traditional preservice student teachers differ from nontraditional preservice student teachers in terms of their scores on the time management construct on the Preservice Teacher Perception Survey?

First, average scores were run for the presurvey responses, and then average scores were run for postsurvey responses. The traditional group was compared to the nontraditional group with the two-sample two-tailed t-test. The traditional preservice teacher group was compared to the nontraditional preservice teacher group to reveal any differences in either internal perceptions or external evaluations using a two-sample t-test that compares two population proportions. The two-sample t-test is useful when comparing two populations, such as traditional preservice student teachers to nontraditional preservice student teachers. The two-sample t-test can be used when the respondents' 
group sizes are different, which was the case in this study. To interpret the results of the two-sample t-tests, the data was analyzed using a standard normal distribution, with a p-value that will determine whether the differences between the traditional preservice teacher and the nontraditional preservice teacher are significant enough to merit further study (Creswell, 2005).

5. How did traditional preservice student teachers compare to nontraditional preservice student teachers in terms of their rates of correlation between their perceptions of the constructs per their Preservice Teacher Perception Postsurveys and their actual assessed performance per their RDI Student Teaching Assessments?

Each postsurvey was compared to its correlating RDI Student Teaching Assessment filled out by both cooperating teacher and supervising teacher, again using a t-test for dependent samples. The t-test for dependent samples is useful because the same group of preservice teachers is being tested twice.

6. How did both groups of preservice student teachers compare before their student teaching experience to after their student teaching experience?

A t-test for dependent samples was run to compare the results of the Preservice Teacher Perception Presurvey to its correlating Postsurvey. Limitations of the Study

This study is limited by its number of participants and by the characteristics of its participants. For the purposes of narrowing the data collection procedure, only secondary preservice teachers were studied; no 
elementary or middle-level preservice teachers were invited to participate. In addition, only preservice teachers at one university, Illinois State University, were invited to participate.

Participants were not offered any external reward for participation, but may have gleaned internal rewards such as satisfaction for helping another student, or positive feelings after reflecting upon their student teaching experience.

\section{Conclusion}

This study was conducted during the spring of 2013 semester. The results were analyzed during the summer and discussed in August 2013. 


\section{CHAPTER IV}

\section{RESULTS}

This chapter provides information about the data and its analysis used in this study. The purpose of this study was to determine whether Illinois State University's secondary education teacher preparation program should differentiate instruction for its two groups of students, traditional and nontraditional, based on four constructs of professional demeanor, interpersonal skills, teaching and learning, and time management. Topics in this chapter include the participants, research questions, and the analysis for each statistical test.

\section{Participants}

To obtain the potential participants, the researcher asked the ISU College of Education Assistant Director of Certification and Data to provide ULIDs (University Login Identification, also known as email addresses) of the preservice teachers. A request for participation was sent via ISU email to the preservice teacher population, of whom there were 292 actively student teaching. Of those 292 preservice teachers, $168(58 \%)$ of them would be considered nontraditional preservice teachers, with 124 (42\%) traditional preservice teachers. 
Of the 43 who responded to the presurvey, two majored in biology, two in business, 11 in English, three in family and consumer science, five in social science/history, 12 in mathematics, two in music, one in physical education, one in physics, two in Spanish, and two in technology.

Table 8

Presurvey Respondent Demographics

\begin{tabular}{lcccc}
\hline \multicolumn{1}{c}{ Major } & \multicolumn{2}{c}{ Traditional } & \multicolumn{2}{c}{ Nontraditional } \\
\hline Biology & 0 & $0 \%$ & 2 & $5 \%$ \\
Business & 1 & $2 \%$ & 1 & $2 \%$ \\
English & 4 & $9 \%$ & 7 & $16 \%$ \\
Family and Consumer Science & 2 & $5 \%$ & 1 & $2 \%$ \\
Social Science/History & 4 & $9 \%$ & 1 & $2 \%$ \\
Mathematics & 10 & $23 \%$ & 2 & $5 \%$ \\
Music & 0 & $0 \%$ & 2 & $5 \%$ \\
Physical Education & 0 & $0 \%$ & 1 & $2 \%$ \\
Physics & 0 & $0 \%$ & 1 & $2 \%$ \\
Spanish & 1 & $2 \%$ & 1 & $2 \%$ \\
Technology & 1 & $2 \%$ & 1 & $2 \%$ \\
& 23 & $52 \%$ & 20 & $47 \%$ \\
\hline
\end{tabular}


Of the 22 who responded to the postsurvey, one majored in biology, one in business, one in English, three in family and consumer science, one in history, nine in mathematics, one in Spanish, and one in technology.

Table 9

Postsurvey Respondent Demographics

\begin{tabular}{lcccc}
\hline \multicolumn{1}{c}{ Major } & \multicolumn{2}{c}{ Traditional } & \multicolumn{2}{c}{ Nontraditional } \\
\hline Biology & 0 & $0 \%$ & 1 & $4.5 \%$ \\
Business & 1 & $4.5 \%$ & 0 & $0 \%$ \\
English & 2 & $9 \%$ & 3 & $13.5 \%$ \\
Family and Consumer Science & 2 & $9 \%$ & 1 & $4.5 \%$ \\
History & 0 & $0 \%$ & 1 & $4.5 \%$ \\
Mathematics & 8 & $36 \%$ & 1 & $4.5 \%$ \\
Spanish & 1 & $4.5 \%$ & 0 & $0 \%$ \\
Technology & 1 & $4.5 \%$ & 0 & $0 \%$ \\
& 15 & $67.5 \%$ & 7 & $31.5 \%$ \\
\hline
\end{tabular}

Of the 14 who agreed to release their evaluations to the researcher, one majored in biology, one in business, four in English, two in family and consumer science, five in mathematics, and one in technology. 
Table 10

RDI Student Teaching Assessment Participants

\begin{tabular}{lcccc}
\hline \multicolumn{1}{l}{ Major } & \multicolumn{2}{l}{ Traditional } & \multicolumn{2}{l}{ Nontraditional } \\
\hline Biology & 0 & $0 \%$ & 1 & $7 \%$ \\
Business & 1 & $7 \%$ & 0 & $0 \%$ \\
English & 2 & $14 \%$ & 2 & $14 \%$ \\
Family and Consumer Science & 1 & $7 \%$ & 1 & $7 \%$ \\
Mathematics & 5 & $36 \%$ & 0 & $0 \%$ \\
Technology & 1 & $7 \%$ & 0 & $0 \%$ \\
& 10 & $71 \%$ & 4 & $28 \%$ \\
\hline
\end{tabular}

Research Questions

The following questions guided the research design, methodology, data collection, and data analysis for this study. The questions incorporated the dependent variables, which are the scores on the RDI Student Teaching Assessment (Appendix A) and the Preservice Teacher Perception Survey (Appendix B). Specifically, the scores were grouped by construct, such as teaching and learning, professional demeanor, interpersonal skills, and time management. The independent variables are the preservice teachers' status in school, as either traditional or nontraditional. The independent variables are defined only by date of birth. 


\section{Research Question 1}

How did traditional preservice student teachers differ from nontraditional preservice student teachers in terms of their scores on the professional demeanor construct of the RDI Student Teaching Assessment?

Table 11

Research Question 1 Results for Professional Demeanor Evaluation

\begin{tabular}{ccccc}
\hline \multicolumn{2}{c}{ Status of respondent } & PD1- eval & PD2-eval & PD3-eval \\
\hline Traditional & 1007 & 3 & 3 & 3 \\
& 1008 & 3 & 3 & 3 \\
& 1012 & 4 & 3 & 2 \\
1019 & 3 & 3 & 3 \\
& 1034 & 3 & 3 & 3 \\
& 1038 & 3 & 3 & 3 \\
& 1039 & 4 & 3 & 3 \\
& 1040 & 3 & 3 & 3 \\
& 1042 & 3 & 3 & 3 \\
& 1032 & 3 & 3 & 3 \\
\hline Nontraditional & 1006 & 3 & 3 & 3 \\
& 1010 & 3 & 3 & 4 \\
& 1021 & 4 & 3 & 2 \\
& 1043 & 3 & 2 & 2.90 \\
Mean (traditional) & & 3.20 & 3.00 & 3.25 \\
Mean (nontraditional) & 3.25 & 2.75 &
\end{tabular}

Note: Raw scores are 1 = unacceptable, 2 = satisfactory, 3 = proficient, $4=e x e m p l a r y$

Mean scores were calculated for each group. The sample size was very small, and the means yielded almost no statistically significant difference between traditional and nontraditional preservice teachers. The biggest difference was in PD3 (used effective classroom management skills to maintain safe and positive learning environments). The nontraditional group scored higher than the traditional group. 
Research Question 2

How did traditional preservice student teachers differ from nontraditional preservice student teachers in terms of their scores on the teaching and learning construct on the RDI Student Teaching Assessment?

Table 12

Research Question 2 Results for Teaching and Learning Evaluation

\begin{tabular}{rccccccc}
\hline Status of respondent & $\begin{array}{c}\text { TL1- } \\
\text { eva }\end{array}$ & $\begin{array}{c}\text { TL2- } \\
\text { eva }\end{array}$ & $\begin{array}{c}\text { TL3- } \\
\text { eva }\end{array}$ & $\begin{array}{c}\text { TL4- } \\
\text { eva }\end{array}$ & $\begin{array}{c}\text { TL5- } \\
\text { eva }\end{array}$ & $\begin{array}{c}\text { TL6- } \\
\text { eva }\end{array}$ & $\begin{array}{c}\text { TL7- } \\
\text { eva }\end{array}$ \\
\hline Traditional 1007 & 3 & 3 & 3 & 3 & 3 & 4 & 3 \\
1008 & 3 & 3 & 3 & 3 & 3 & 3 & 3 \\
1012 & 2 & 4 & 4 & 3 & 3 & 3 & 3 \\
1019 & 3 & 3 & 3 & 3 & 3 & 3 & 3 \\
1034 & 3 & 3 & 3 & 3 & 3 & 3 & 3 \\
1038 & 3 & 3 & 3 & 3 & 3 & 3 & 3 \\
1039 & 3 & 3 & 3 & 4 & 4 & 3 & 3 \\
1040 & 3 & 3 & 3 & 3 & 3 & 2 & 3 \\
1042 & 3 & 3 & 3 & 3 & 3 & 3 & 3 \\
1032 & 3 & 3 & 3 & 3 & 3 & 3 & 3 \\
\hline Nontraditional 1006 & 3 & 4 & 3 & 3 & 4 & 3 & 3 \\
1010 & 3 & 3 & 3 & 3 & 4 & 4 & 3 \\
1021 & 4 & 4 & 3 & 4 & 4 & 4 & 4 \\
1043 & 3 & 2 & 2 & 3 & 3 & 2 & 3 \\
Mean (traditional) & 2.90 & 3.10 & 3.10 & 3.10 & 3.10 & 3.00 & 3.00 \\
Mean (nontraditional) & 3.25 & 3.25 & 2.75 & 3.25 & 3.75 & 3.25 & 3.25 \\
\hline Nat
\end{tabular}

Note: Raw scores are $1=$ unacceptable, $2=$ satisfactory, $3=$ proficient, $4=$ exemplary

Mean scores were calculated for each group. The sample size was very small, and the means yielded almost no statistically significant difference between traditional and nontraditional preservice teachers. However, the average score for nontraditional preservice teacher was higher in every Teaching and Learning question except for TL3, which is "Appropriately integrates instructional resources, including technology, into the curriculum to support student learning." 


\section{Research Question 3}

How did traditional preservice student teachers differ from nontraditional preservice student teachers in terms of their scores on the interpersonal skills construct on the RDI Student Teaching Assessment?

Table 13

Research Question 3 Results for Interpersonal Skills Evaluation

\begin{tabular}{|c|c|c|c|c|}
\hline \multicolumn{2}{|c|}{ Status of respondent } & IS1-eva & IS2-eva & IS3-eva \\
\hline \multirow[t]{10}{*}{ Traditional } & 1007 & 4 & 3 & 3 \\
\hline & 1008 & 3 & 3 & 3 \\
\hline & 1012 & 3 & 3 & 2 \\
\hline & 1019 & 3 & 3 & 3 \\
\hline & 1034 & 3 & 3 & 3 \\
\hline & 1038 & 3 & 3 & 3 \\
\hline & 1039 & 4 & 4 & 3 \\
\hline & 1040 & 3 & 3 & 3 \\
\hline & 1042 & 3 & 3 & 3 \\
\hline & 1032 & 3 & 3 & 3 \\
\hline \multirow[t]{4}{*}{ Nontraditional } & 1006 & 3 & 4 & 3 \\
\hline & 1010 & 4 & 3 & 2 \\
\hline & 1021 & 4 & 4 & 4 \\
\hline & 1043 & 3 & 2 & 2 \\
\hline \multicolumn{2}{|c|}{ Mean (Traditional) } & 3.20 & 3.10 & 2.90 \\
\hline \multicolumn{2}{|c|}{ Mean (Nontraditional) } & 3.50 & 3.25 & 2.75 \\
\hline
\end{tabular}

Note: Raw scores are 1 = unacceptable, 2 = satisfactory, 3 = proficient, $4=$ exemplary

Mean scores were calculated for each group. The sample size was very small, and the means yielded almost no statistically significant difference between traditional and nontraditional preservice teachers. However, the average score for nontraditional preservice teacher was higher in every Interpersonal Skills question except for IS3, which is "Includes families in the education process." 


\section{Research Question 4}

How did traditional preservice student teachers differ from nontraditional preservice student teachers in terms of their scores on the time management construct on the Preservice Teacher Perception Survey?

Table 14

Research Question 4 Results for Time Management Presurvey

\begin{tabular}{rcccccc}
\hline Status of Respondent & TM1-pre & TM2-pre & TM3-pre & TM4-pre & TM5-pre \\
\hline Traditional & 1002 & 4 & 4 & 30 & 10 & 10 \\
& 1007 & 3 & 3 & 14 & 7 & 5 \\
1008 & 4 & 4 & 20 & 5 & 10 \\
1009 & 4 & 4 & 10 & 5 & 5 \\
1012 & 4 & 4 & 10 & 20 & 5 \\
1014 & 4 & 4 & 7 & 3 & 5 \\
1018 & 4 & 3 & 18 & 10 & 2 \\
1019 & 3 & 3 & 12 & 10 & 8 \\
1027 & 3 & 3 & 30 & 2 & 5 \\
1034 & 3 & 2 & 20 & 10 & 10 \\
1038 & 3 & 3 & 20 & 5 & 10 \\
1039 & 4 & 4 & 8 & 8 & 15 \\
1040 & 3 & 3 & 8 & 3 & 5 \\
1042 & 4 & 4 & 5 & 5 & 5 \\
1032 & 2 & 2 & 30 & 20 & 10 \\
\hline Nontraditional & 1006 & 4 & 4 & 10 & 10 & 5 \\
1010 & 4 & 3 & 15 & 5 & 10 \\
1011 & 3 & 3 & 10 & 5 & 5 \\
1013 & 4 & 4 & 12 & 10 & 5 \\
1021 & 4 & 4 & 15 & 8 & 6 \\
1029 & 4 & 4 & 5 & 5 & 10 \\
1043 & 4 & 4 & 15 & 10 & 8 \\
Mean (Traditional) & 3.47 & 3.33 & 16.13 & 8.20 & 7.33 \\
Mean (Nontraditional) & 3.86 & 3.71 & 11.71 & 7.57 & 7.00 \\
\hline Note: Raw scas a
\end{tabular}

Note: Raw scores are 1 = unacceptable, 2 = satisfactory, 3 = proficient, $4=$ =xemplary

The first two items are scores on a Likert scale, with 1 being the lowest (strongly disagree) and 4 being the highest (strongly agree.) The next three scores are estimates of how much time preservice teachers anticipate spending 
outside school "planning instruction per week" (TM3), "assessing student progress per week" (TM4), and "performing other educational tasks related to student teaching" (TM5). The first two Likert-score means show that nontraditional preservice teachers anticipated being able to manage their time effectively both at school and outside school with more confidence that traditional preservice teachers. In addition, traditional preservice teachers anticipated spending more time outside school working on various student-teaching tasks.

Table 15

Research Question 4 Results for Time Management Postsurvey

\begin{tabular}{|c|c|c|c|c|c|c|}
\hline \multicolumn{2}{|c|}{ Status of Respondent } & TM1-post & TM2-post & TM3-post & TM4-post & TM5-post \\
\hline Traditional & 1002 & 4 & 4 & 20 & 10 & 10 \\
\hline & 1007 & 3 & 3 & 20 & 5 & 2 \\
\hline & 1008 & 4 & 4 & 20 & 5 & 7 \\
\hline & 1009 & 4 & 4 & 1 & 1 & 0 \\
\hline & 1012 & 3 & 3 & 15 & 5 & 10 \\
\hline & 1014 & 2 & 3 & 20 & 10 & 20 \\
\hline & 1018 & 4 & 4 & 25 & 5 & 10 \\
\hline & 1019 & 4 & 4 & 30 & 10 & 10 \\
\hline & 1027 & 3 & 3 & 50 & 10 & 10 \\
\hline & 1034 & 3 & 3 & 30 & 15 & 10 \\
\hline & 1038 & 4 & 4 & 5 & 2 & 2 \\
\hline & 1039 & 4 & 4 & 10 & 10 & 10 \\
\hline & 1040 & 3 & 3 & 15 & 5 & 2 \\
\hline & 1042 & 4 & 4 & 5 & 5 & 5 \\
\hline & 1032 & 1 & 1 & 25 & 20 & 10 \\
\hline Nontraditional & 1006 & 4 & 4 & 15 & 10 & 10 \\
\hline & 1010 & 4 & 3 & 50 & 15 & 35 \\
\hline & 1011 & 4 & 4 & 15 & 10 & 10 \\
\hline & 1013 & 4 & 4 & 10 & 21 & 3 \\
\hline & 1021 & 4 & 4 & 25 & 10 & 6 \\
\hline & 1029 & 4 & 4 & 10 & 10 & 20 \\
\hline & 1043 & 4 & 4 & 20 & 15 & 15 \\
\hline Mean (Tradition & & 3.33 & 3.40 & 19.40 & 7.87 & 7.87 \\
\hline Mean (Nontradi & tional) & 4.00 & 3.86 & 20.71 & 13.00 & 14.14 \\
\hline
\end{tabular}

Note: Raw scores are 1 = unacceptable, 2 = satisfactory, 3 = proficient, $4=$ exemplary 
The first two items are scores on a Likert scale, with 1 being the lowest (strongly disagree) and 4 being the highest (strongly agree.) The next three scores are estimates of how much time preservice teachers anticipate spending outside school "planning instruction per week" (TM3), "assessing student progress per week" (TM4), and "performing other educational tasks related to student teaching" (TM5). The first two Likert-score means show that nontraditional preservice teachers felt that they had managed their time at the school and outside the school effectively than the traditional preservice teachers felt.

The next three scores reveal that nontraditional preservice teachers spent much more time outside school doing student-teaching tasks than traditional preservice teachers.

Table 16

Research Question 4 Results for t-test, Time Management

\begin{tabular}{|c|c|c|c|c|c|c|}
\hline Status of Resp & dent & TM1 & TM2 & TM3 & TM4 & TM5t \\
\hline Traditional & 1002 & 0 & 0 & -10 & 0 & 0 \\
\hline & 1007 & 0 & 0 & 6 & -2 & -3 \\
\hline & 1008 & 0 & 0 & 0 & 0 & -3 \\
\hline & 1009 & 0 & 0 & -9 & -4 & -5 \\
\hline & 1012 & -1 & -1 & 5 & -15 & 5 \\
\hline & 1014 & -2 & -1 & 13 & 7 & 15 \\
\hline & 1018 & 0 & 1 & 7 & -5 & 8 \\
\hline & 1019 & 1 & 1 & 18 & 0 & 2 \\
\hline & 1027 & 0 & 0 & 20 & 8 & 5 \\
\hline & 1034 & 0 & 1 & 10 & 5 & 0 \\
\hline & 1038 & 1 & 1 & -15 & -3 & -8 \\
\hline & 1039 & 0 & 0 & 2 & 2 & -5 \\
\hline & 1040 & 0 & 0 & 7 & 2 & -3 \\
\hline & 1042 & 0 & 0 & 0 & 0 & 0 \\
\hline & 1032 & -1 & -1 & -5 & 0 & 0 \\
\hline Nontraditiona & 1006 & 0 & 0 & 5 & 0 & 5 \\
\hline
\end{tabular}




\begin{tabular}{|c|c|c|c|c|c|}
\hline 1010 & 0 & 0 & 35 & 10 & 25 \\
\hline 1011 & 1 & 1 & 5 & 5 & 5 \\
\hline 1013 & 0 & 0 & -2 & 11 & -2 \\
\hline 1021 & 0 & 0 & 10 & 2 & 0 \\
\hline 1029 & 0 & 0 & 5 & 5 & 10 \\
\hline 1043 & 0 & 0 & 5 & 5 & 7 \\
\hline t-test & 0.32 & 0.44 & 0.27 & 0.10 & 0.35 \\
\hline Mean (Traditional) & -0.13 & 0.07 & 3.27 & -0.33 & 0.53 \\
\hline Mean Nontraditional) & 0.14 & 0.14 & 9.00 & 5.43 & 7.14 \\
\hline
\end{tabular}

Note: Numbers reveal the presurvey scores subtracted from the postsurvey scores.

The traditional group was compared to the nontraditional group with the 2-sample two-tailed t-test. This means the averages were computed first for presurvey and postsurvey. Then the average scores for the traditional group were compared to the average scores for the nontraditional group. While the statistics reveal nothing of significance as the $p$-values are too large, the data suggests that nontraditional preservice teachers spent quite a bit more time on student-teaching activities outside the school than did traditional student teachers.

\section{Research Question 5}

How did traditional preservice student teachers compare to nontraditional preservice student teachers in terms of their rates of correlation between their perceptions of the constructs per their Preservice Teacher

Perception Surveys and their actual assessed performance per their RDI Student Teaching Assessments?

Table 17

Research Question 5 Results for t-test, Professional Demeanor

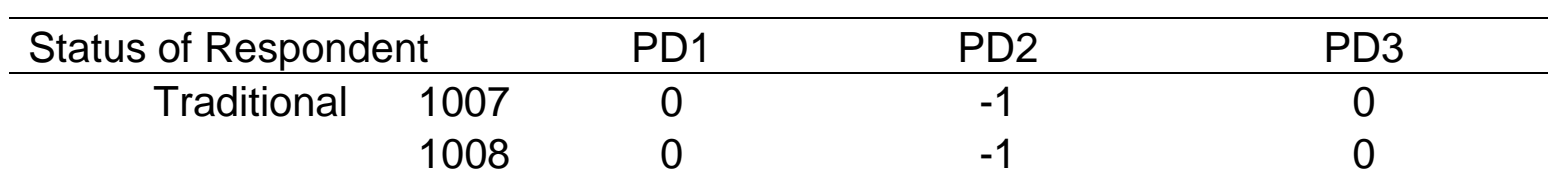




\begin{tabular}{lcccc} 
& 1012 & 1 & -1 & -1 \\
& 1019 & -1 & -1 & -1 \\
& 1034 & 0 & 0 & 0 \\
& 1038 & -1 & 0 & -1 \\
& 1039 & 0 & -1 & -1 \\
& 1040 & 0 & -1 & 0 \\
& 1042 & -1 & -1 & -1 \\
& 1032 & -1 & 1 & 0 \\
\hline Nontraditional & 1006 & -1 & -1 & 0 \\
& 1010 & 0 & 0 & -1 \\
t-test & 1021 & 0 & -1 & 0 \\
Mean(traditional) & 1043 & -1 & -2 & -2 \\
Mean(nontraditional) & & 0.30 & 0.42 & 0.33 \\
\hline No:Numbers revealt & -0.30 & -0.60 & -0.50 \\
\hline
\end{tabular}

Note: Numbers reveal the postsurvey scores subtracted from the evaluation scores.

None of the $p$-values were found to be statistically significant; however observation of the tabulated scores reveals that the nontraditional group rated their performance higher than their evaluators, which included their cooperating teachers and university supervisors, rated them. The traditional group was a little more accurate about assessing their performance.

Table 18

Research Question 5 Results for t-test, Teaching and Learning

\begin{tabular}{ccccccccc}
\hline \multicolumn{2}{c}{ Status of Respondent } & TL1 & TL2 & TL3 & TL4 & TL5 & TL6 & TL7 \\
\hline Traditional & 1007 & 0 & 0 & 0 & 0 & 0 & 1 & 0 \\
& 1008 & -1 & 0 & -1 & -1 & -1 & -1 & -1 \\
& 1012 & 0 & 0 & 0 & -1 & -1 & -1 & -1 \\
& 1019 & -1 & -1 & -1 & -1 & -1 & -1 & -1 \\
& 1034 & -1 & 0 & -1 & 0 & 0 & 0 & 0 \\
& 1038 & -1 & -1 & -1 & -1 & -1 & -1 & -1 \\
& 1039 & -1 & -1 & -1 & 0 & 0 & -1 & -1 \\
& 1040 & -1 & -1 & -1 & -1 & 0 & -1 & 0 \\
Nontraditional & 1042 & -1 & 0 & 0 & 0 & -1 & -1 & -1 \\
& 1032 & -1 & -1 & -1 & -1 & -1 & -1 & -1 \\
\hline & 1006 & -1 & 0 & -1 & -1 & 0 & -1 & -1 \\
& 1010 & -1 & 0 & 0 & -1 & 0 & 0 & -1
\end{tabular}




\begin{tabular}{lcccccccc} 
& 1021 & 0 & 0 & -1 & 0 & 0 & 0 & 0 \\
& 1043 & -1 & -2 & -2 & -1 & -1 & -2 & -1 \\
t-test & & 0.43 & 0.50 & $0 . .26$ & 0.32 & 0.14 & 0.46 & 0.44 \\
Mean(traditional) & & -0.80 & -0.50 & -0.70 & -0.60 & -0.60 & -0.70 & -0.70 \\
Mean(nontraditional) & & -0.75 & -0.50 & -1.00 & -0.75 & -0.25 & -0.75 & -0.75 \\
\hline
\end{tabular}

Note: Numbers reveal the postsurvey scores subtracted from the evaluation scores.

None of the $p$-values were found to be statistically significant; however observation of the tabulated scores reveals that the both groups rated their actual teaching and learning performance higher than their evaluators rated them.

Table 19

Research Question 5 Results for t-test, Interpersonal Skills

\begin{tabular}{lcccc}
\hline Status of Respondent & & IS1 & IS2 & IS3 \\
\hline Traditional & 1007 & 0 & 0 & 0 \\
& 1008 & -1 & -1 & 1 \\
& 1012 & -1 & -1 & -1 \\
& 1019 & -1 & -1 & 0 \\
& 1034 & -1 & -1 & 0 \\
& 1038 & -1 & -1 & 0 \\
& 1039 & 0 & 0 & -1 \\
& 1040 & 0 & 0 & 0 \\
Nontraditional & 1042 & -1 & -1 & -1 \\
& 1032 & -1 & -1 & 1 \\
& 1006 & -1 & 0 & -1 \\
t-test & 1010 & 0 & -1 & 0 \\
Mean(traditional) & 1021 & 0 & 0 & 0 \\
Mean(nontraditional) & 1043 & -1 & -2 & -2 \\
\hline Ne: No. & & 0.29 & 0.47 & 0.14 \\
& & -0.70 & -0.70 & -0.10 \\
& -0.50 & -0.75 & -0.75 \\
\hline
\end{tabular}

Note: Numbers reveal the postsurvey scores subtracted from the evaluation scores.

The t-test did not have a significant enough $p$-value for these numbers to be significant. The sample size is very small. Again, the groups both rated their own performance on the interpersonal skills section to be higher than their evaluators rated their performance. 


\section{Research Question 6}

How did both groups of preservice student teachers compare before their student teaching experience to after their student teaching experience?

Table 20

Research Question 6 Results for t-test, Professional Demeanor

\begin{tabular}{|c|c|c|c|c|c|c|c|}
\hline \multicolumn{2}{|c|}{ Status of Respondent } & PD1 & PD2 & PD3 & PD4 & PD5 & PD6 \\
\hline \multirow[t]{15}{*}{ Traditional } & 1002 & 0 & 0 & -1 & 0 & 0 & 0 \\
\hline & 1007 & 0 & 1 & 0 & 0 & 0 & -1 \\
\hline & 1008 & -1 & 0 & -1 & 0 & 0 & 0 \\
\hline & 1009 & 0 & 0 & 0 & 0 & 0 & 1 \\
\hline & 1012 & -1 & 0 & -1 & -1 & 0 & -1 \\
\hline & 1014 & 0 & -1 & -1 & -1 & 0 & 1 \\
\hline & 1018 & 0 & -1 & -1 & 0 & -1 & -1 \\
\hline & 1019 & 0 & 0 & 0 & 0 & 0 & 2 \\
\hline & 1027 & 1 & 1 & 0 & 0 & 1 & 0 \\
\hline & 1034 & 0 & 0 & 0 & 1 & 0 & 2 \\
\hline & 1038 & 0 & -1 & 0 & 1 & 0 & 0 \\
\hline & 1039 & 0 & 0 & 0 & 0 & 0 & 1 \\
\hline & 1040 & 0 & 0 & 0 & 0 & 0 & 0 \\
\hline & 1042 & 0 & 0 & 0 & 0 & 0 & 0 \\
\hline & 1032 & 0 & -2 & -1 & 2 & 0 & 0 \\
\hline \multirow[t]{7}{*}{ Nontraditional } & 1006 & 1 & 1 & 1 & 1 & 0 & 0 \\
\hline & 1010 & -1 & -1 & 0 & 0 & 1 & -1 \\
\hline & 1011 & 0 & 0 & 0 & 1 & 0 & 0 \\
\hline & 1013 & 1 & -1 & -1 & 0 & 1 & -1 \\
\hline & 1021 & 0 & 0 & 0 & 0 & 0 & -1 \\
\hline & 1029 & 1 & 1 & 1 & 1 & 0 & 0 \\
\hline & 1043 & 0 & 0 & 0 & 1 & 1 & 0 \\
\hline \multicolumn{2}{|l|}{ t-test } & 0.07 & 0.15 & 0.03 & 0.04 & 0.02 & 0.01 \\
\hline \multicolumn{2}{|l|}{ Mean(traditional) } & -0.10 & -0.20 & -0.40 & 0.10 & 0.00 & 0.30 \\
\hline \multicolumn{2}{|c|}{ Mean(nontraditional) } & 0.29 & 0.00 & 0.14 & 0.57 & 0.43 & -0.43 \\
\hline
\end{tabular}

Note: Numbers reveal the presurvey scores subtracted from the postsurvey scores. 
The t-test shows a statistical significance in four of the items, PD3 (using effective classroom management skills), PD4 (felt like a "real teacher"), PD5 (can't wait to get own classroom so can teach "my way"), and PD6 (apprehensive about being in own classroom). Traditional preservice teachers under-anticipated their perceived effectiveness at classroom management skills; they gave themselves a higher number for that item on the presurvey than they did on the postsurvey. Nontraditional preservice teachers felt more strongly at the end of the semester about being eager to be in their own classrooms, teaching their own way. And nontraditional preservice teachers were also less apprehensive at the end of the semester than they were at the beginning of the semester, while traditional preservice teachers were more apprehensive.

Table 21

Research Question 6 Results for t-test, Teaching and Learning

\begin{tabular}{lccccccccccc}
\hline Status of Respondent & TL1 & TL2 & TL3 & TL4 & TL5 & TL6 & TL7 & TL8 & TL9 & TL10 \\
\hline Traditional & 1002 & -1 & 0 & 0 & -1 & 0 & 0 & 0 & 0 & 0 & 0 \\
& 1007 & 0 & 0 & 0 & 0 & 0 & 0 & 0 & 0 & 0 & 0 \\
& 1008 & 0 & -1 & 0 & 0 & 0 & 0 & 0 & 0 & -1 & 0 \\
& 1009 & -1 & -1 & 0 & 0 & 0 & 0 & 0 & -1 & -1 & 0 \\
& 1012 & -2 & 0 & 0 & 0 & 0 & 0 & 0 & 0 & 0 & 0 \\
& 1014 & 0 & 0 & -1 & -1 & -1 & -1 & -1 & 1 & 1 & 1 \\
& 1018 & -1 & -1 & -1 & -1 & -1 & -1 & -1 & 0 & -2 & -1 \\
& 1019 & 0 & 0 & 0 & 0 & 0 & 0 & 0 & 0 & 0 & 1 \\
& 1027 & 1 & 1 & 1 & 1 & 1 & 1 & 0 & 1 & -1 & 0 \\
& 1034 & 1 & 0 & 1 & 0 & -1 & -1 & 0 & -1 & -1 & 0 \\
& 1038 & 0 & 0 & 0 & 0 & 0 & 0 & 0 & 0 & 0 & 0 \\
& 1039 & 0 & 0 & 0 & 0 & 0 & 0 & 0 & 0 & 0 & 0 \\
& 1040 & 1 & 1 & 1 & 1 & 0 & 0 & 0 & 0 & 0 & -1 \\
& 1042 & 0 & -1 & -1 & -1 & 0 & 0 & 0 & -1 & 0 & 0 \\
& 1032 & 0 & 0 & 0 & 0 & 0 & 0 & 0 & 0 & -3 & 0 \\
\hline Nontraditional & 1006 & 1 & 1 & 1 & 1 & 1 & 1 & 1 & 0 & 0 & 1 \\
& 1010 & 0 & 0 & -1 & 0 & 0 & 0 & 0 & 1 & -2 & -1 \\
& 1011 & 0 & -1 & 0 & 1 & 0 & 0 & 0 & 0 & 0 & 0
\end{tabular}




\begin{tabular}{lccccccccccc} 
& 1013 & 1 & 0 & -1 & 1 & 1 & 0 & -1 & 0 & 0 & 1 \\
1021 & 0 & 0 & 0 & 0 & 0 & 0 & 0 & 0 & 0 & 0 \\
1029 & 1 & 1 & 1 & 1 & 0 & 0 & 0 & -1 & 0 & 2 \\
& 1043 & 0 & 0 & 0 & 0 & 0 & 0 & 0 & 0 & 0 & 0 \\
t-test & 0.02 & 0.10 & 0.25 & 0.01 & 0.03 & 0.05 & 0.15 & 0.20 & 0.13 & 0.08 \\
Mean(traditional) & -0.13 & -0.13 & 0.00 & -0.13 & -0.13 & -0.13 & -0.13 & -0.07 & -0.53 & 0.00 \\
Mean(nontraditional) & 0.43 & 0.14 & 0.00 & 0.57 & 0.29 & 0.14 & 0.00 & 0.00 & -0.29 & 0.43 \\
\hline \multicolumn{7}{l}{ Note: Numbers reveal the presurvey scores subtracted from the postsurvey scores. }
\end{tabular}

The t-test shows a statistical significance in four items: TL1 (planned and developed lessons to meet instructional goals and serve diverse learners), TL4 (used multiple assessment strategies), TL5 (used reflection to improve instruction) and TL6 (demonstrated persistence in helping all students learn.) For TL1, the traditional group anticipated at the beginning of the semester that they would do better at developing and planning lessons than they felt they did at the end. For TL4, again the traditional group thought they would use multiple assessment strategies at the beginning of the semester, but at the end of the semester they felt less strongly. The same result is for TL5 and TL6; the traditional group gave higher anticipatory scores than actual self-evaluative scores.

Table 22

Research Question 6 Results for t-test, Interpersonal Skills

\begin{tabular}{|c|c|c|c|c|c|c|c|}
\hline \multicolumn{2}{|c|}{ Status of Respondent } & IS1 & IS2 & IS3 & IS4 & IS5 & IS6 \\
\hline \multirow[t]{9}{*}{ Traditional } & 1002 & 0 & 0 & -1 & 0 & 0 & 0 \\
\hline & 1007 & 1 & 0 & 0 & 0 & 0 & -1 \\
\hline & 1008 & 0 & 0 & -2 & 0 & 0 & 0 \\
\hline & 1009 & 0 & 0 & -1 & 0 & 0 & 0 \\
\hline & 1012 & 0 & 0 & -1 & -1 & 1 & 0 \\
\hline & 1014 & 0 & -1 & -2 & 2 & -2 & 0 \\
\hline & 1018 & 0 & 0 & -1 & -1 & 0 & 1 \\
\hline & 1019 & 0 & 0 & -1 & 2 & 1 & 1 \\
\hline & 1027 & 0 & 0 & 0 & 0 & 0 & 0 \\
\hline
\end{tabular}




\begin{tabular}{|c|c|c|c|c|c|c|c|}
\hline & 1034 & 0 & 0 & -1 & 0 & 1 & 1 \\
\hline & 1038 & 0 & 0 & -1 & 0 & 0 & 1 \\
\hline & 1039 & 0 & 0 & 0 & 0 & 0 & 0 \\
\hline & 1040 & -1 & 0 & 0 & 0 & 0 & 0 \\
\hline & 1042 & 0 & 0 & 0 & -1 & 0 & 0 \\
\hline & 1032 & 0 & 0 & -2 & 1 & -2 & -1 \\
\hline \multirow{7}{*}{ Nontraditional } & 1006 & 1 & 1 & 1 & -1 & 0 & 0 \\
\hline & 1010 & 0 & 0 & -1 & 0 & 1 & -1 \\
\hline & 1011 & 0 & 0 & -1 & 2 & 0 & 1 \\
\hline & 1013 & 0 & 0 & 0 & 0 & 0 & 0 \\
\hline & 1021 & 0 & 0 & 0 & 0 & 0 & 0 \\
\hline & 1029 & 0 & 0 & 0 & 0 & 0 & 0 \\
\hline & 1043 & 0 & 0 & 0 & -1 & 0 & -1 \\
\hline \multicolumn{2}{|l|}{ t-test } & 0.11 & 0.06 & 0.01 & 0.20 & 0.11 & 0.10 \\
\hline \multicolumn{2}{|c|}{ Mean(traditional) } & 0.00 & -0.07 & -0.87 & 0.13 & -0.07 & 0.13 \\
\hline \multicolumn{2}{|c|}{ Mean(nontraditional) } & 0.14 & 0.14 & -0.14 & 0.00 & 0.14 & -0.14 \\
\hline
\end{tabular}

Note: Numbers reveal the presurvey scores subtracted from the postsurvey scores.

The t-test shows significance in only one of the items, IS3 (included families in the education process). Both groups of preservice teachers anticipated including families in the education process at a higher score than they self-evaluated, but the traditional group had a more dramatic difference in their results than nontraditional group.

Table 23

Research Question 6 Results for t-test, Time Management

\begin{tabular}{ccccccc}
\hline \multicolumn{2}{c}{ Status of Respondent } & TM1 & TM2 & TM3 & TM4 & TM5 \\
\hline Traditional & 1002 & 0 & 0 & -10 & 0 & 0 \\
& 1007 & 0 & 0 & 6 & -2 & -3 \\
& 1008 & 0 & 0 & 0 & 0 & -3 \\
1009 & 0 & 0 & -9 & -4 & -5 \\
& 1012 & -1 & -1 & 5 & -15 & 5 \\
& 1014 & -2 & -1 & 13 & 7 & 15 \\
1018 & 0 & 1 & 7 & -5 & 8 \\
1019 & 1 & 1 & 18 & 0 & 2 \\
1027 & 0 & 0 & 20 & 8 & 5 \\
1034 & 0 & 1 & 10 & 5 & 0 \\
1038 & 1 & 1 & -15 & -3 & -8
\end{tabular}




\begin{tabular}{lcccccc} 
& 1039 & 0 & 0 & 2 & 2 & -5 \\
& 1040 & 0 & 0 & 7 & 2 & -3 \\
& 1042 & 0 & 0 & 0 & 0 & 0 \\
& 1032 & -1 & -1 & -5 & 0 & 0 \\
\hline Nontraditional & 1006 & 0 & 0 & 5 & 0 & 5 \\
& 1010 & 0 & 0 & 35 & 10 & 25 \\
& 1011 & 1 & 1 & 5 & 5 & 5 \\
& 1013 & 0 & 0 & -2 & 11 & -2 \\
& 1021 & 0 & 0 & 10 & 2 & 0 \\
& 1029 & 0 & 0 & 5 & 5 & 10 \\
t-test & 1043 & 0 & 0 & 5 & 5 & 7 \\
Mean(traditional) & & 0.07 & 0.19 & 0.08 & 0.01 & 0.03 \\
Mean(nontraditional) & 0.13 & 0.07 & 3.27 & -0.33 & 0.53 \\
\hline \multicolumn{2}{l}{ Nonn Numb } & 0.14 & 0.14 & 9.00 & 5.43 & 7.14 \\
\hline
\end{tabular}

Note: Numbers reveal the presurvey scores subtracted from the postsurvey scores.

The t-test shows significance in two of the items, TM4 (hours outside school assessing student progress per week) and TM5 (hours outside school performing other educational tasks related to student-teaching). The traditional group reported spending fewer hours per week on assessing student progress than they had planned, while the nontraditional group reported spending more hours than they had planned. Both groups reported spending more hours performing other educational tasks related to student-teaching than they had anticipated, but the nontraditional group had more of a difference between the amount of time they anticipated spending, and the amount of time they actually spent.

\section{Limitations}

All five of the mathematics preservice teachers had identical evaluations, with straight "threes" for every item. So for every item on their evaluation, their evaluators (team of cooperating teacher and university supervisor) rated them as "proficient (novice teacher)." While five mathematics teachers out of a possible 
44 mathematics preservice teachers who student-taught this semester is a very small sample, it prompted an inquiry from the researcher to the Assistant Director of Certification and Data at the College of Education Clinical Experiences and Certification Processes. The Assistant Director indicated via email that such scoring might be an indication of a difference in the math department's philosophy of grading (L. A. Steffen, personal communication, June 17, 2013). Summary

While the number of participants was too small to make sweeping generalizations about the nature of traditional and nontraditional preservice student teachers, the data reveals enough of a difference between traditional and nontraditional preservice student teachers to merit further discussion and to generate both implications and suggestions. 


\section{CHAPTER V \\ DISCUSSION AND IMPLICATIONS}

This chapter provides a summary of the analysis of this study. The purpose of this study was to determine whether Illinois State University's secondary education teacher preparation program should differentiate instruction for its two groups of students, traditional and nontraditional, based on four constructs of professional demeanor, interpersonal skills, teaching and learning, and time management. Topics in this chapter include the research questions with their results and implications; limitations; and recommendations for further research.

Research Questions

\section{Research Question 1}

How did traditional preservice student teachers differ from nontraditional preservice student teachers in terms of their scores on the professional demeanor construct of the RDI Student Teaching Assessment?

Results. The biggest difference was in PD3 (used effective classroom management skills to maintain safe and positive learning environments). The nontraditional group scored higher than the traditional group. This is unsurprising, as nontraditional preservice teachers are older than preservice teachers and therefore have more years between their students and themselves. This can 
certainly make gaining students' respect for their authority easier for the more mature preservice teachers. Also, it is likely that the nontraditional group has had more experience and practice than the traditional group managing people, in previous employment or even with their own children.

Implications. Teaching preservice teachers about classroom management remains a common and constant issue. Teacher preparation programs might consider providing better clinical experiences specifically for classroom management. For example, perhaps preservice teachers could be assigned to conduct a guided observation with classroom management as the sole focus. Perhaps more emphasis should be placed on understanding the learners' needs in the classroom to which one is assigned to student teach.

Assuming nontraditional preservice teachers look as if they are older than traditional preservice teachers, the nontraditional group might have that slight advantage when it comes to classroom management. Proper attire and mature poise might also enable traditional preservice teachers to garner students' respect and obedience. Teacher preparation programs can provide instruction for effective nonverbal methods of communicating with students, giving preservice teachers yet another way to establish authority.

Finally, teacher preparation programs might consider requiring or suggesting that their preservice teacher spend their summers doing internships at summer camps. This type of immersion into the adolescent world might teach them about their future learners, about their own capability of managing these learners, and even whether they want to continue to pursue teaching as a career. 


\section{Research Question 2}

How did traditional preservice student teachers differ from nontraditional preservice student teachers in terms of their scores on the teaching and learning construct on the RDI Student Teaching Assessment?

Results. The average score for nontraditional preservice teachers was higher in every teaching and learning question except for TL3, which is "Appropriately integrates instructional resources, including technology, into the curriculum to support student learning." This is interesting because it harkens back to the notion of teachers teach how they were taught. Traditional preservice teachers, current millennials, are digital natives who most likely went to schools where their teachers incorporated technology. They are probably familiar with several technological methods of helping their students understand concepts and may reach for technology naturally to enhance their lessons, whereas nontraditional preservice teachers are less familiar with technology in schools and may tend to force or add technology as an afterthought. It may not come as naturally to them as it does to traditional preservice teachers.

Otherwise, the nontraditional group on average scored higher on the other six items of the teaching and learning section of the RDI Student Teaching Assessment. These items capture the essence of student teaching: the planning and implementing of lessons, and assessing whether the students learned the lessons.

Implications. Teacher preparation programs should think about requiring more preparation regarding technology, particularly for their digital immigrants. 
While an entire semester's course might not be necessary, perhaps providing workshops with hands-on activities could enable preservice teachers to practice using the technology that they will most likely be required to use.

At some point in the future, this will become less necessary, as the digital natives become more prevalent and the digital immigrants become less apparent.

\section{Research Question 3}

How did traditional preservice student teachers differ from nontraditional preservice student teachers in terms of their scores on the interpersonal skills construct on the RDI Student Teaching Assessment?

Results. The average score for nontraditional preservice teacher was higher in every interpersonal skills question except for IS3, which is "Includes families in the education process." This could indicate a disconnect between the philosophy of the ISU College of Education and the real-world experience of teaching. The RDI Student Teaching Assessment lists this as one of its fifteen topics on which preservice teachers are rated, but it may prove to be more ambiguous and less necessary than its original intent. Nontraditional preservice teachers may have found it artificial to include families in the learning process. Perhaps they have children in school and as parents are not included in the learning process of their own children. By the time students are in secondary schools, their families may be less easily defined after marriages, deaths, divorces, remarriages, etc. In addition, parents who stayed home while their children were younger may have rejoined the work force as their children 
became more independent. Knowing that student learners are mostly, at the secondary level, responsible for their own learning may be a reason that nontraditional preservice teachers may have focused more on getting their students to learn than on incorporating their families into the learning process.

Implications. This particular item on the RDI Student Teaching Assessment seems the farthest from the control of the preservice student teacher. While it is important for teachers to know their learners in order to best help them attach new learning to their own life experiences, it may be very difficult for someone who is just learning to teach to accomplish within such a short period of time. Secondary students are generally a busy group of people, with extracurricular activities and jobs in addition to their hours of homework. Additionally, at this point in their adolescence, they are taking more responsibility for their own learning and relying less on assistance with homework from their parents.

Perhaps this RDI item should be reconsidered and either reworked or removed entirely from the Student Teaching Assessment. If not, then the teacher education program could make a stronger attempt to instill its importance and show its relevance to nontraditional preservice teachers.

\section{Research Question 4}

How did traditional preservice student teachers differ from nontraditional preservice student teachers in terms of their scores on the time management construct on the Preservice Teacher Perception Survey? 
Results. Although the data was not statistically significant, some assumptions can be made. Nontraditional preservice teachers anticipated being able to manage their time effectively both at school and outside school with more confidence than traditional preservice teachers anticipated for themselves. Postsurvey scores show that the same nontraditional group felt that they had indeed managed their time more effectively than the traditional group felt about their own time management. In addition, traditional preservice teachers anticipated spending more time outside school working on various studentteaching tasks, but in fact nontraditional preservice teachers spent much more time outside school doing student-teaching tasks than traditional preservice teachers.

This shows that the older, more mature group with more life experiences was better able to manage their time effectively than the less mature group. Interestingly, though, the nontraditional group underestimated at the beginning how much time would be required for completing student-teaching activities outside the school setting. It is as if the more time exists between being a student in high school and between student teaching in a high school, the less likely a preservice teacher will remember how much work there is for a teacher to do.

Implications. Teacher preparation programs might consider providing better clinical experiences specifically for time management. For example, perhaps preservice teachers could be assigned to conduct a guided observation with time management as the sole focus. In the semesters before student teaching, in addition to observing classes, they could observe a planning session 
composed of a teacher team or even just one teacher. They could observe classroom set-up procedures before students arrive, watch departmental goalsetting meetings, attend curriculum writings. Also, cooperating teachers can help by revealing and demonstrating their own uses of didactic time and time capital. They could be more intentional about revealing how they plan for lessons and how they structure their daily, weekly, quarterly, and yearly work.

Finally, teacher preparation programs should consider conducting workshops, not necessarily classes, about time management. Several ways to think about time and plan for time should be presented at these workshops, along with some ideas about implementation that preservice teachers can use immediately. It might also be beneficial to discuss with preservice teachers, as part of their coursework, the amount of time to anticipate spending on various student-teaching tasks.

Research Question 5

How did traditional preservice student teachers compare to nontraditional preservice student teachers in terms of their rates of correlation between their perceptions of the constructs per their Preservice Teacher Perception Surveys and their actual assessed performance per their RDI Student Teaching Assessments?

Results. The sample size was too small to make comparisons between how preservice teachers rated themselves and how their university supervisors and cooperating teachers rated them. For the most part, the preservice teachers 
gave themselves higher ratings than their supervisors did, with very little difference between the two groups.

Implications. Because the sample size was so small and the differences between the two groups so insignificant, generalizations at this point would be difficult to make. However, because across the board most preservice teachers had inflated perceptions of their performance as student teachers, the cooperating teachers and university supervisors could be more transparent about their evaluation process. When cooperating teachers discuss with their preservice teachers how the preservice teachers are doing in the classroom, they could model their discussions using the terms of the RDI Student Teaching Assessment. Both cooperating teachers and their student teachers could keep reflective logs, structured using the RDI guidelines, with anecdotal notes to provide a springboard for weekly discussions about the student-teaching process.

Research Question 6

How did both groups of preservice student teachers compare before their student teaching experience to after their student teaching experience?

Results. In the construct of professional demeanor, traditional preservice teachers under-anticipated their perceived effectiveness at classroom management skills; they gave themselves a higher number for that item on the presurvey than they did on the postsurvey. Nontraditional preservice teachers felt more strongly at the end of the semester than at the beginning of the semester about being eager to be in their own classroom, teaching their own way. And 
nontraditional preservice teachers were also less apprehensive at the end of the semester than they were at the beginning of the semester, while the opposite held true for the traditional preservice teachers.

For the variable teaching and learning, the traditional group anticipated at the beginning of the semester that they would do better at developing and planning lessons than they felt they did at the end of the semester. Also, the traditional group thought they would use multiple assessment strategies at the beginning of the semester, but at the end they felt less strongly. This held true for the items about using reflection to improve instruction and demonstrating persistence in helping all students learn. In all four of these items, the nontraditional group under-anticipated their performance at the beginning, then evaluated themselves higher at the end.

As for interpersonal skills, both groups of preservice teachers anticipated including families in the education process at a higher score than they selfevaluated at the end of the semester, but the traditional group had a more dramatic difference in their results than the nontraditional group.

Finally, in the construct time management, the traditional group reported spending fewer hours per week on assessing student progress than they had planned, while the nontraditional group reported spending more hours than planned. Both groups reported spending more hours performing other educational tasks related to student teaching than they had anticipated, but the nontraditional group had more of a difference between the amount of time they anticipated spending, and the amount of time they actually spent. 
Implications. The differences indicate a need for more differentiation between traditional preservice teachers and nontraditional preservice teachers. Because the very nature of the nontraditional preservice teacher indicates both more maturity and more life experiences upon which to attach new learning, nontraditional preservice teachers present as a different type of student than traditional preservice teachers. This may call for two different types of classes, with a "Teaching 101a" class for traditional preservice teachers and a "Teaching 101 b" class for nontraditional preservice teachers. Then instructors should pay attention to the levels of pedagogy and andragogy they incorporate into their lessons.

Perhaps the use of more workshops throughout the teacher education program could achieve the same purpose, providing extra guidance for nontraditional preservice teachers to use and incorporate technology into their classrooms, and extra guidance for traditional preservice teachers to manage their time, both didactic and time capital.

It might be beneficial as well to discuss with student teachers the amount of time they will have to devote to their student teaching. Nontraditional students might not have planned to spend as much time as they actually did, and this may have led to other conflicts in aspects that are unique to nontraditional students, such as family obligations or possibly even work obligations.

Conclusions

While more research is indicated, some implications of the findings point to better and differentiated preparation for the two groups of student teachers, 
the traditional and the nontraditional. The results of this study show that traditional student teachers had higher expectations and likely higher confidence going into their student-teaching experience than they had at the end of their experience. Perhaps teacher educators can focus more on realistic expectations for this group so they are not overly confident at the beginning or overly disappointed at the end of student teaching. Conversely, nontraditional student teachers had lower expectations and likely lower confidence going into their student-teaching experience. Perhaps teacher educators can focus more on getting nontraditional student teachers to draw upon their own life experience to inspire confidence at the beginning of the student-teaching experience. Nontraditional students know more than they think they do.

Also, all five of the mathematics preservice teachers had identical evaluations, with straight "threes" for every item. So for every item on their evaluation, their evaluators (team of cooperating teacher and university supervisor) rated them as "proficient (novice teacher)." While five mathematics teachers out of a possible forty-four mathematics preservice teachers who student-taught this semester is a very small sample, it prompted an inquiry from the researcher to the Assistant Director of Certification and Data at the College of Education Clinical Experiences and Certification Processes. The Assistant Director indicated via email that such scoring might be an indication of a difference in the math department's philosophy of grading. If further investigation into this apparent difference in evaluating student teachers yields a difference in 
the math department's philosophy of grading, the next step might be a discussion of departmental differences in the interest of fairness to students.

\section{Recommendations for Future Research}

The number of participants in this study was disappointingly small. While the results definitely show that differences do exist between the traditional and nontraditional preservice teacher, the results do not show much specifically in each of the constructs of professional demeanor, teaching and learning, interpersonal skills, and time management. One recommendation is to conduct this same study again next year, attempting to get more participants. A couple of ways to do that might be a personal plea in the classroom before the student teachers go into the field and are away from the direct influence of their teacher educators. Another way might be to offer some sort of incentive, such as gift cards. A second recommendation is to conduct a qualitative approach to this data, by conducting case studies of some traditional preservice teachers and nontraditional preservice teachers. In addition to verifying what the data from this study suggests, other details could be obtained such as why a participant gives a certain response, rather than just the response itself.

The nontraditional preservice teacher group could be further divided and investigated as to status of parenthood and military service. These two subgroups have specific scaffolding from life experiences and may have characteristics that could cause teacher educators to differentiate their instruction. 
It might also be valuable to look at the evaluation process at Illinois State University by department. If discrepancies in grading philosophies exist, this might merit further review.

This study was conducted at only one level of teaching, secondary, and at only one teacher education program, Illinois State University. The study could easily be replicated at the elementary level or at any other teacher education program, by modifying the Preservice Teacher Perception Survey to correlate with the appropriate student teaching assessment. 


\section{REFERENCES}

Advisory Committee on Student Financial Assistance. (2012). Pathways to success: integrating learning with life and work to increase national college completion. U.S. Congress and Secretary of Education. Washington, D.C.: Advisory Committee on Student Financial Assistance.

Al-Bataineh, A. (2009). An examination of pre-service teacher preparedness: a cooperating teacher perspective. The International Journal of Learning, 16 (5), 231-246.

Assude, T. (2005). Time management in the work economy of a class, a case study: integration of Cabri in primary school mathematics teaching. Educational Studies in Mathematics, 59 (1-3), 183-203.

Baloche, L., Hynes, J., \& Berger, H. (1996). Moving toward the integration of professional and general education. Action in Teacher Education, 18, 1-9.

Banks, F., Leach, J., \& Moon, B. (2005). Extract from new understandings of teachers' pedagogic knowledge. Curriculum Journal, 16 (3), 331-340.

Baumlein, G. (2004). The cyberstudent. In L. C. Englemann (Ed.), Teaching Nursing: The Art and Science (pp. 434-446). Glen Ellyn, Illinois: College of DuPage Press. 
Birrell, J. R., \& Bullough, R. V. (2005). Teaching with a peer: a follow-up study of the 1st year of teaching. Action in Teacher Education, 27 (1), 72-81.

Britzman, D. P. (2003). Practice makes practice: a critical study of learning to teach. Albany: State University of New York Press.

Brouwer, N., \& Korthagen, F. Can teacher education make a difference? American Educational Research Journa , 42 (1), 153-224.

Brown, S. D. (2004). State Certification Requirements for History Teachers (Report No. EDO-SO-2003-14. (D. Office of Educational Research and Improvement (ED) Washington, Ed.) ERIC Digest.

Byrd, D. M., \& McIntyre, D. J. (1996). Introduction: using research to strengthen field experiences. In D. J. McIntyre, \& D. M. Byrd (Eds.), Preparing tomorrow's teachers: the field experience (p. xiv). Thousand Oaks, CA: Corwin Press, Inc.

Carpenter, T. P., \& Lehrer, R. (1999). Teaching and learning mathematics with understanding. In E. Fennema, \& T. A. Romberg (Eds.), Mathematics classrooms that promote understanding (pp. 19-320). Mahwah, New Jersey: Erlbaum.

Chen, Y., Lee, Y.-T., Pethel, O. L., Gutowitz, M. S., \& Kirk, R. M. (2012). Age differences in goal concordance, time use, and well-being. Educational Gerontology, 38 (11), 742-752.

Creswell, J. W. (2005). Educational Research. Upper Saddle River, New Jersey: Pearson Prentice Hall. 
Darling-Hammond, L. (1999). Educating Teachers for the next century:

Rethinking practice and policy. In G. A. Griffin (Ed.), The education of teachers (pp. 221-256). Chicago: National Society for the Study of Education.

Darling-Hammond, L., \& Bransford, J. (Eds.). (2005). Preparing Teachers for a Changing World: What Teachers Should Learn and Be Able To Do. San Francisco: Jossey-Bass.

Darling-Hammond, L., Chung, R., \& Frelow, F. (2002). Variation in teacher preparation: how well do different pathways prepare teachers to teach? Journal of Teacher Education, 53 (4), 286-302.

Enz, B. J., Freeman, D. J., \& Wallin, M. B. (1996). Roles and responsibilities of the student teacher supervisor: matches and mismatches in perception. In D. J. McIntyre \& D. M. Byrd (Eds.), Preparing tomorrow's teachers: the field experience (pp. 131-150). Thousand Oaks, California: Corwin Press, Inc.

Feiman-Nemser, S. (2001). From preparation to practice: designing a contiuum to strengthen and sustain teaching. Teachers College Record, 103 (6), 1033-55.

Feiman-Nemser, S., \& Beasley, K. (2007). Discovering and sharing knowledge. In D. Carroll, H. Featherstone, J. Featherstone, S. Feiman-Nemser, \& D. Roosevelt (Eds.), Transforming Teacher Education (pp. 139-160). Cambridge, Massachusetts: Harvard Education Press. 
Foote, C., Vermette, P., Wisniewski, S., Agnello, A., \& Pagano, C. (2000). The characteristics of bad high school teachers reveal avoidable behaviors for new teachers. Education, 121 (1), 128-135.

Goubeaud, K., \& Yan, W. (2004). Teacher educators' teaching methods, assessment, and grading: a comparison of higher education faculty's instructional practices. Teacher Educator, 40 (1), 1-16.

Griffin, G. A. (1999). Changes in teacher education: looking to the future.. In G. A. Griffin (Ed.), The education of teachers (p. 15). Chicago: National Society for the Study of Education.

Grossman, P., \& Thompson, C. (2004). District policy and beginning teachers: A lens on teacher learning. Educational Evaluation and Policy Analysis, 26 (4), 281-301.

Henry, M. A., \& Weber, A. (2010). Supervising student teachers the professional way (Seventh ed.). Lanham, MD: Rowman \& Littlefield Education.

Horowitz, F. D., Darling-Hammond, L., Bransford, J., Comer, J., Rosebrock, K., \& Austin, K. (2005). Eduating teachers for developmentally appropriate practice. In L. Darling-Hammond, \& J. Bransford (Eds.), Preparing teachers for a changing world (p. 107). San Francisco: Jossey-Bass.

Howe, N., \& Strauss, W. (2000). Millennials rising: the next great generation. New York: Vintage.

Illinois State Board of Education. (2012). Alternative teacher certification. Retrieved from Educator Certification: http://www.isbe.state.il.us/profprep/PDFs/sec21-5b.pdf 
Illinois State Board of Education. (2013, July). Steps to obtaining an educator license in Illinois. Retrieved July 2103, from Educator Licensure: http://www.isbe.state.il.us/licensure/pdf/ed-lic-steps1212.pdf Illinois State University College of Education Teacher Education Center. (2013). Clinical Experiences and Student Teaching. Retrieved July 19, 2013, from Illinois State University College of Education Cecilia J. Lauby Teacher Education Center: http://education.illinoisstate.edu/teacher_education /clinical/

Illinois State University College of Education Teacher Education Center. (2013). Cooperating Teachers. Retrieved July 19, 2013, from Illinois State University College of Education Cecilia J. Lauby Teacher Education Center: http://education.illinoisstate.edu/teacher_education/cooperating/ Illinois State University College of Education Teacher Education Center. (2013). University Supervisors. Retrieved July 19, 2013, from Illinois State University College of Education Cecilia J. Lauby Teacher Education Center: http://education.illinoisstate.edu/teacher_education/supervisors/ Justice, E. M., \& Dornan, T. M. (2001). Metacognitive differences between traditional-age and nontraditional-age college students. Adult Education Quarterly, 5 (3), p236-249.

Kazis, R., Callahan, A., \& Davidson, C. (2007). Adult learners in higher education: barriers to success and strategies to improve results, employment, and training administration. Washington, D.C.: U.S. Department of Labor, Employment, and Training Administration. 
Killen, R. (2007). Effective teaching strategies: lessons from research and practice. South Melbourne: Thomson Social Science Press.

Killen, R. (1994). Student teachers' perceptions of successful and unsuccessful events during practice teaching. ERIC.

Kniseley, M. (2011, May). Win a teaching job. Retrieved April 19, 2012, from winateachingjob.com: http://www.winateachingjob.com/2011/05/applyingfor-jobs-understanding.html

Knobloch, N. A., \& Whittington, M. S. (2002). Novice teachers' perceptions of support, teacher preparation quality, and student teaching experience related to teacher efficacy. Journal of Vocational Education Research, 27, $331-41$.

Knowles, M. S. (1984). Andragogy in action. San Francisco: Jossey-Bass, Inc. Kugel, P. (1993, January). How professors develop as teachers. Studies in Higher Education, 18 (3).

Lee, D., \& Lamport, M. A. (2011). Non-traditional entrants to the profession of teaching: motivations and experiences of second-career teachers. Christian Perspectives in Education, 4 (2).

Lortie, D. C. (1975). Schoolteacher: a sociological study. Chicago: The University of Chicago Press.

Massengill, D., Mahlios, M., \& Barry, A. (2005). Metaphors and sense of teaching: how these constructs influence novice teachers. Teaching Education, 16 (3), 213-229. 
Mastrilli, T., \& Sardo-Brown, D. (2002). Novice Teachers' Cases: A vehicle for reflective practice. Education, 123 (1), 56 - 63.

Merriam, S. B. (2001). Andragogy and self-directed learning: pillars of adult learning theory. New Directions for Adult and Continuing Education (80), 3-13.

Moore, R. (2003). Reexamining the field experiences of preservice teachers. Journal of Teacher Education, 54 (1), 31-42.

Moyer, B. A., \& Wittmann-Price, R. A. (Eds.). (2008). Nursing education: foundations for practice excellence. Philadelphia: F. A. Davis.

Nasah, A., DaCosta, B., Kinsell, C., \& Seok, S. (n.d.). The digital literacy debate: an investigation of digital propensity and information and communicative technology. Etr\&D - Educational Technology Research and Development, $58(5), 531-555$.

No Child Left Behind Act of 2001, 20 U.S.C. $§ 6319$ (2008).

Novak, D., \& Knowles, J. G. (1992). Life histories and the transition to teaching as a second career. American Education Research Association. San Francisco, CA: ERIC.

Oblinger, D. (2003, July/August). Boomers, gen-xers, \& millennials: understanding the new students. Educause , 38 (4), pp. 36-47.

Olejnik, S. F. (1984). Planning educational research: determining the necessary sample size. Journal of Experimental Education, 53, p. 40-48.

Paccion, A. V., McWhorter, B. A., \& Richburg, R. W. (2000). Ten years on the fast track. In D. J. Mcintyre, \& D. M. Byrd (Eds.), Research on Effective 
Models for Teacher Education (pp. 218-234). Thousand Oaks, California: Corwin Press, Inc.

Pauly, E. (2002). Nobody told me about May. Journal of Adolescent \& Adult Literacy, 46 (4), 284.

Pearson Education Incorporated. (Retrieved October 11, 2011). Illinois Certification Testing System. http://www.icts.nesinc.com/IL16_ passingrequirements.asp. (2001).

Prensky, M. (2001). Digital natives, digital immigrants. On the Horizon, 9, 1-6.)

Rajuan, M., Beijaard, D., \& Verloop, N. (2007). The role of the cooperating teacher: bridging the gap between the expectations of cooperating teachers and student teachers. Mentoring \& Tutoring: Partnership in Learning , 15 (3), 223-242.

Salkind, N. J. (2004). Statistics for people who (think they) hate statistics (Second ed.). Thousand Oaks, CA: Sage Publications, Inc.

Shulman, L. S. (1986). Those who understand: knowledge growth in teaching. Educational Researcher, 15 (2), 4-14.

Singer-Gabella, M., Iddings, C., Paulsen, K., Smithey, M., Hardenbrook, M., Palmeri, A., et al. (2007). From teacher education to P-12 learning outcomes: the new burden of proof. Teaching \& Learning, 21 (2/3), 115138.

Sosniak, L. A. (1998). Professional and subject matter knowledge for teacher education. Yearbook (National Society for the Study of Education), 98 (1), 185-204. 
Student teaching for secondary and K-12 majors. (2011). Retrieved December 2, 2011, from Teacher Education at Illinois State University: http//teacheredcenter.illinoisstate.edu/clinicalexpstudentteaching/ secondary/studentteaching.html.

Swain, C. (2006). Preservice teachers self-assessment using technology: determining what is worthwhile and looking for changes in daily teaching and learning practices. Journal of Technology \& Teacher Education, 14 (1), 29-59.

Teacher Certification. (2011). Retrieved October 10, 2011. Illinois State University, Office of the University Registrar. Normal, IL: http://www.registrar.ilstu.edu/teacher_certification/.

The National Academy of Education, Committee on Teacher Education. (2005). A good teacher in every classroom: preparing the highly qualified teachers our children deserve. (L. Darling-Hammond, \& J. Baratz-Snowden, Eds.) San Francisco: Jossey-Bass.

Tyler, K. (2007, May). The tethered generation. HR Magazine, 52 (5), pp. 40-46. Vogt, W. P. (2007). Quantitative research methods for professionals. Boston, MA: Pearson Education, Inc.

Wilcox, D. R., \& Samaras, A. P. (2009). Examining our career switching teachers' first year of teaching: implications for alternative teacher education program design. Teacher Education Quarterly, 36 (4), 173-191. 
Wilson, C. L. (2000). English student teachers' perceptions of successful student teaching (Vol. Ed.D. dissertation). Urbana-Champaign, Illinois: University of Illinois at Urbana-Champaign.

Wilson, S. M., Floden, R. E., \& Ferrini-Mundy, J. (2002). Teacher preparation research: an insider's view from the outside. Journal of Teacher Education, 53 (3), 190-204. 


\section{APPENDIX A}

\section{REALIZING THE DEMOCRATIC IDEAL STUDENT TEACHING ASSESSMENT}

This rubric presents elements of student teaching performance that are (1) broadly applicable to the variety of programs at Illinois State University and (2) aligned with the Ethical and Intellectual Commitments (codes noted in brackets, full text at the end of this document) associated with Realizing the Democratic Ideal, the University's conceptual framework for teacher education. This assessment is not a grading scale.

\begin{tabular}{|c|c|c|c|c|c|}
\hline $\begin{array}{l}\text { Indicator } \\
\text { The teacher } \\
\text { candidate, in a } \\
\text { professional } \\
\text { and ethical } \\
\text { manner,: }\end{array}$ & Unacceptable (1) & $\begin{array}{l}\text { Satisfactory (2) } \\
\text { Novice Teacher }\end{array}$ & $\begin{array}{l}\text { Proficient (3) } \\
\text { Novice Teacher }\end{array}$ & $\begin{array}{l}\text { Exemplary (4) } \\
\text { Experienced } \\
\text { Teacher, rare to } \\
\text { be seen in } \\
\text { student } \\
\text { teaching }\end{array}$ & $\begin{array}{l}\text { Examples of } \\
\text { Possible Evidence }\end{array}$ \\
\hline \multicolumn{6}{|c|}{ Regarding professional demeanor } \\
\hline $\begin{array}{l}1 . \\
\text { Demonstrates } \\
\text { specialized } \\
\text { content } \\
\text { knowledge for } \\
\text { teaching. } \\
\text { [IC1: } \\
\text { knowledge] }\end{array}$ & $\begin{array}{l}\text { Lacks mastery of } \\
\text { the content. If } \\
\text { content errors } \\
\text { are made, the } \\
\text { candidate } \\
\text { frequently } \\
\text { neither } \\
\text { acknowledges } \\
\text { nor rectifies the } \\
\text { error. }\end{array}$ & $\begin{array}{l}\text { Shows mastery } \\
\text { of most content } \\
\text { taught. When } \\
\text { content errors } \\
\text { are made, the } \\
\text { errors are } \\
\text { usually } \\
\text { acknowledged } \\
\text { and rectified in } \\
\text { an appropriate } \\
\text { and timely } \\
\text { manner. }\end{array}$ & $\begin{array}{l}\text { Shows mastery } \\
\text { of virtually all } \\
\text { content taught. } \\
\text { When content } \\
\text { errors are made, } \\
\text { the errors are } \\
\text { acknowledged } \\
\text { and rectified in } \\
\text { an appropriate } \\
\text { and timely } \\
\text { manner. Draws } \\
\text { on connected } \\
\text { knowledge to } \\
\text { enrich learning } \\
\text { experiences. }\end{array}$ & $\begin{array}{l}\text { Shows mastery } \\
\text { of the content } \\
\text { needed for } \\
\text { teaching. When } \\
\text { content errors } \\
\text { are made, the } \\
\text { errors are } \\
\text { acknowledged } \\
\text { and rectified in } \\
\text { an appropriate } \\
\text { and timely } \\
\text { manner. The } \\
\text { candidate } \\
\text { integrates } \\
\text { understanding } \\
\text { of specific } \\
\text { content, } \\
\text { pedagogy, } \\
\text { issues that } \\
\text { impact student } \\
\text { learning, and } \\
\text { assessment. }\end{array}$ & $\begin{array}{l}\text { Lesson/Unit/Curr. } \\
\text { Plans } \\
\text { Bulletin boards } \\
\text { Student work } \\
\text { samples } \\
\text { Goal statements } \\
\text { Enhancement } \\
\text { Activities }\end{array}$ \\
\hline
\end{tabular}




\begin{tabular}{|c|c|c|c|c|c|}
\hline $\begin{array}{l}\text { Indicator } \\
\text { The teacher } \\
\text { candidate, in a } \\
\text { professional } \\
\text { and ethical } \\
\text { manner,: }\end{array}$ & Unacceptable (1) & $\begin{array}{l}\text { Satisfactory (2) } \\
\text { Novice Teacher }\end{array}$ & $\begin{array}{l}\text { Proficient (3) } \\
\text { Novice Teacher }\end{array}$ & $\begin{array}{l}\text { Exemplary (4) } \\
\text { Experienced } \\
\text { Teacher, rare to } \\
\text { be seen in } \\
\text { student } \\
\text { teaching }\end{array}$ & $\begin{array}{l}\text { Examples of } \\
\text { Possible Evidence }\end{array}$ \\
\hline $\begin{array}{l}2 . \\
\text { Communicates } \\
\text { effectively } \\
\text { (written, } \\
\text { verbal, and } \\
\text { nonverbal). } \\
\text { [IC5: } \\
\text { enthusiasm] }\end{array}$ & $\begin{array}{l}\text { Communicates in } \\
\text { ways that do not } \\
\text { promote a } \\
\text { positive effect on } \\
\text { learning. } \\
\text { Communications } \\
\text { are poorly } \\
\text { organized, } \\
\text { inappropriate, } \\
\text { and/or are error- } \\
\text { ridden. }\end{array}$ & $\begin{array}{l}\text { Communicates in } \\
\text { ways that are } \\
\text { effective, } \\
\text { respectful of the } \\
\text { audience, } \\
\text { accurate, and } \\
\text { meaningful. }\end{array}$ & $\begin{array}{l}\text { Consistently } \\
\text { communicates in } \\
\text { ways that are } \\
\text { effective, } \\
\text { respectful of the } \\
\text { audience, } \\
\text { accurate, and } \\
\text { meaningful and } \\
\text { that contribute } \\
\text { to a positive } \\
\text { learning } \\
\text { environment. }\end{array}$ & $\begin{array}{l}\text { Consistently } \\
\text { communicates } \\
\text { in ways that are } \\
\text { effective, } \\
\text { respectful of } \\
\text { the audience, } \\
\text { accurate, and } \\
\text { meaningful and } \\
\text { that contribute } \\
\text { to a positive } \\
\text { learning } \\
\text { environment. } \\
\text { The candidate } \\
\text { identifies } \\
\text { barriers to } \\
\text { effective } \\
\text { communication } \\
\text { and uses } \\
\text { appropriate } \\
\text { strategies to } \\
\text { overcome } \\
\text { them. }\end{array}$ & $\begin{array}{l}\text { Bulletin boards } \\
\text { Lesson Videos } \\
\text { Letters to parents } \\
\text { Notes to students } \\
\text { Candidate-made } \\
\text { materials }\end{array}$ \\
\hline
\end{tabular}




\begin{tabular}{|c|c|c|c|c|c|}
\hline $\begin{array}{l}\text { Indicator } \\
\text { The teacher } \\
\text { candidate, in a } \\
\text { professional } \\
\text { and ethical } \\
\text { manner,: }\end{array}$ & Unacceptable (1) & $\begin{array}{l}\text { Satisfactory (2) } \\
\text { Novice Teacher }\end{array}$ & $\begin{array}{l}\text { Proficient (3) } \\
\text { Novice Teacher }\end{array}$ & $\begin{array}{l}\text { Exemplary (4) } \\
\text { Experienced } \\
\text { Teacher, rare to } \\
\text { be seen in } \\
\text { student } \\
\text { teaching }\end{array}$ & $\begin{array}{l}\text { Examples of } \\
\text { Possible Evidence }\end{array}$ \\
\hline $\begin{array}{l}\text { 3. Uses } \\
\text { effective } \\
\text { classroom } \\
\text { management } \\
\text { skills to } \\
\text { maintain safe } \\
\text { and positive } \\
\text { learning } \\
\text { environments. } \\
\text { [EC4: respect } \\
\text { for learners; } \\
\text { EC3: regard for } \\
\text { learning] }\end{array}$ & $\begin{array}{l}\text { Does not } \\
\text { attempt to } \\
\text { establish a } \\
\text { positive, } \\
\text { developmentally } \\
\text { appropriate } \\
\text { learning } \\
\text { environment. } \\
\text { The candidate } \\
\text { does not address } \\
\text { inappropriate } \\
\text { student } \\
\text { behavior. Safety } \\
\text { issues are not } \\
\text { addressed } \\
\text { appropriately. }\end{array}$ & $\begin{array}{l}\text { Plans for a } \\
\text { positive, } \\
\text { developmentally } \\
\text { appropriate } \\
\text { learning } \\
\text { environment. } \\
\text { When student } \\
\text { behavior } \\
\text { concerns arise } \\
\text { the candidate } \\
\text { makes an } \\
\text { attempt to } \\
\text { address the } \\
\text { inappropriate } \\
\text { behavior. The } \\
\text { candidate } \\
\text { recognizes and } \\
\text { rectifies } \\
\text { potential safety } \\
\text { hazards. }\end{array}$ & $\begin{array}{l}\text { Implements and } \\
\text { adapts plans for } \\
\text { the learning } \\
\text { environment to } \\
\text { meet emerging } \\
\text { needs (students, } \\
\text { curricula, etc.). } \\
\text { The candidate } \\
\text { employs multiple } \\
\text { strategies to } \\
\text { effectively } \\
\text { manage } \\
\text { behavior } \\
\text { concerns. The } \\
\text { candidate } \\
\text { conscientiously } \\
\text { scans the } \\
\text { environment for } \\
\text { potential safety } \\
\text { hazards and } \\
\text { rectifies them } \\
\text { promptly. }\end{array}$ & $\begin{array}{l}\text { Creates a } \\
\text { learning } \\
\text { community } \\
\text { based on trust, } \\
\text { respect, and } \\
\text { reciprocity. The } \\
\text { candidate } \\
\text { analyzes } \\
\text { behavior } \\
\text { concerns and } \\
\text { anticipates } \\
\text { alternative } \\
\text { influences to } \\
\text { more effectively } \\
\text { redirect student } \\
\text { behavior. The } \\
\text { candidate } \\
\text { maintains a safe } \\
\text { learning } \\
\text { environment } \\
\text { and raises } \\
\text { students' } \\
\text { awareness of } \\
\text { safety concerns. }\end{array}$ & $\begin{array}{l}\text { Supervisor } \\
\text { Reports } \\
\text { Video of lesson } \\
\text { Reflections }\end{array}$ \\
\hline
\end{tabular}




\begin{tabular}{|c|c|c|c|c|c|}
\hline $\begin{array}{l}\text { Indicator } \\
\text { The teacher } \\
\text { candidate, in a } \\
\text { professional } \\
\text { and ethical } \\
\text { manner,: }\end{array}$ & Unacceptable (1) & $\begin{array}{l}\text { Satisfactory (2) } \\
\text { Novice Teacher }\end{array}$ & $\begin{array}{l}\text { Proficient (3) } \\
\text { Novice Teacher }\end{array}$ & $\begin{array}{l}\text { Exemplary (4) } \\
\text { Experienced } \\
\text { Teacher, rare to } \\
\text { be seen in } \\
\text { student } \\
\text { teaching }\end{array}$ & $\begin{array}{l}\text { Examples of } \\
\text { Possible Evidence }\end{array}$ \\
\hline $\begin{array}{l}4 . \\
\text { Demonstrates } \\
\text { professional } \\
\text { practice } \\
\text { consistent with } \\
\text { an appropriate } \\
\text { philosophy of } \\
\text { education. } \\
\text { [EC3: regard } \\
\text { for learning] }\end{array}$ & $\begin{array}{l}\text { Makes } \\
\text { instructional } \\
\text { choices that are } \\
\text { inconsistent with } \\
\text { one's philosophy } \\
\text { of education or } \\
\text { has an } \\
\text { inappropriate } \\
\text { philosophy of } \\
\text { education. }\end{array}$ & $\begin{array}{l}\text { Attempts to align } \\
\text { learning } \\
\text { activities with } \\
\text { one's philosophy } \\
\text { of education. }\end{array}$ & $\begin{array}{l}\text { Aligns } \\
\text { educational } \\
\text { practice (e.g., } \\
\text { planning, } \\
\text { implementation, } \\
\text { interactions with } \\
\text { students) with } \\
\text { one's philosophy } \\
\text { of education. }\end{array}$ & $\begin{array}{l}\text { Adapts one's } \\
\text { philosophy of } \\
\text { education } \\
\text { through } \\
\text { reflection on } \\
\text { experience and } \\
\text { deeper } \\
\text { understanding } \\
\text { of teaching and } \\
\text { learning. The } \\
\text { philosophy is } \\
\text { reflected widely } \\
\text { in activities and } \\
\text { interactions } \\
\text { with children, } \\
\text { families, and } \\
\text { other education } \\
\text { professionals. }\end{array}$ & $\begin{array}{l}\text { Portfolio } \\
\text { including essay } \\
\text { (position paper) } \\
\text { Reflections } \\
\text { Supervisor } \\
\text { Reports } \\
\text { Lesson Plans }\end{array}$ \\
\hline $\begin{array}{l}\text { 5. Seeks } \\
\text { appropriate } \\
\text { opportunities } \\
\text { for } \\
\text { professional } \\
\text { development. } \\
\text { [IC4: } \\
\text { resourceful; } \\
\text { IC5: } \\
\text { enthusiasm] }\end{array}$ & $\begin{array}{l}\text { Participates in no } \\
\text { supplemental } \\
\text { opportunities for } \\
\text { professional } \\
\text { development. }\end{array}$ & $\begin{array}{l}\text { Participates in } \\
\text { appropriate } \\
\text { professional } \\
\text { development } \\
\text { activities, } \\
\text { beyond those } \\
\text { required by the } \\
\text { school or district } \\
\text { (more than } \\
\text { internet } \\
\text { research). }\end{array}$ & $\begin{array}{l}\text { Applies insights } \\
\text { (knowledge, } \\
\text { skills, etc.) } \\
\text { gained from } \\
\text { professional } \\
\text { development to } \\
\text { practice. }\end{array}$ & $\begin{array}{l}\text { Provides } \\
\text { professional } \\
\text { development } \\
\text { for others (e.g., } \\
\text { by sharing } \\
\text { insights gained } \\
\text { or organizing } \\
\text { professional } \\
\text { development } \\
\text { opportunities). }\end{array}$ & $\begin{array}{l}\text { Reflections on } \\
\text { attendance at } \\
\text { professional } \\
\text { conferences } \\
\text { Membership in } \\
\text { professional } \\
\text { organization }\end{array}$ \\
\hline
\end{tabular}




\begin{tabular}{|c|c|c|c|c|c|}
\hline $\begin{array}{l}\text { Indicator } \\
\text { The teacher } \\
\text { candidate, in a } \\
\text { professional } \\
\text { and ethical } \\
\text { manner,: }\end{array}$ & $\begin{array}{l}\text { Unacceptable } \\
\text { (1) }\end{array}$ & $\begin{array}{l}\text { Satisfactory (2) } \\
\text { Novice Teacher }\end{array}$ & $\begin{array}{l}\text { Proficient (3) } \\
\text { Novice Teacher }\end{array}$ & $\begin{array}{l}\text { Exemplary (4) } \\
\text { Experienced } \\
\text { Teacher, rare to be } \\
\text { seen in student } \\
\text { teaching }\end{array}$ & $\begin{array}{l}\text { Possible } \\
\text { Evidence }\end{array}$ \\
\hline \multicolumn{6}{|c|}{ Regarding teaching and learning } \\
\hline $\begin{array}{l}\text { 6. Plans and } \\
\text { develops } \\
\text { lessons to meet } \\
\text { instructional } \\
\text { goals and serve } \\
\text { diverse } \\
\text { learners. } \\
\text { [IC3: } \\
\text { understand } \\
\text { learning; EC3: } \\
\text { regard for } \\
\text { learning; IC2: } \\
\text { diversity among } \\
\text { learners; EC1: } \\
\text { sensitivity- } \\
\text { diversity] }\end{array}$ & $\begin{array}{l}\text { Does not plan } \\
\text { well or plans do } \\
\text { not connect to } \\
\text { instructional } \\
\text { goals. }\end{array}$ & $\begin{array}{l}\text { Plans lessons } \\
\text { that align with } \\
\text { stated } \\
\text { instructional } \\
\text { goals and may } \\
\text { reflect some } \\
\text { consideration of } \\
\text { the needs of } \\
\text { diverse learners. }\end{array}$ & $\begin{array}{l}\text { Plans engaging } \\
\text { lessons that } \\
\text { align with } \\
\text { stated } \\
\text { instructional } \\
\text { goals and } \\
\text { explicitly } \\
\text { address the } \\
\text { needs of } \\
\text { diverse } \\
\text { learners. }\end{array}$ & $\begin{array}{l}\text { Plans creative, } \\
\text { robust and } \\
\text { engaging lessons } \\
\text { that align with } \\
\text { inter-related } \\
\text { instructional goals } \\
\text { (e.g., grade level } \\
\text { curriculum, state } \\
\text { learning standards, } \\
\text { school-level } \\
\text { initiatives and } \\
\text { personal } \\
\text { development) to } \\
\text { address the needs } \\
\text { of diverse learners } \\
\text { appropriately. }\end{array}$ & 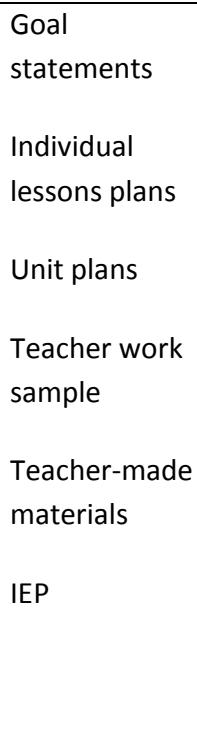 \\
\hline $\begin{array}{l}7 . \\
\text { Differentiates } \\
\text { instruction. } \\
\text { [IC3: } \\
\text { understand } \\
\text { learning; IC2: } \\
\text { diversity among } \\
\text { learners] }\end{array}$ & $\begin{array}{l}\text { Uses a single } \\
\text { method to teach } \\
\text { students and } \\
\text { cannot adapt } \\
\text { instruction to } \\
\text { help students } \\
\text { learn. }\end{array}$ & $\begin{array}{l}\text { Uses a few } \\
\text { different } \\
\text { methods and } \\
\text { shows some } \\
\text { evidence of } \\
\text { adapting } \\
\text { instruction to } \\
\text { help students } \\
\text { learn. }\end{array}$ & $\begin{array}{l}\text { Uses multiple } \\
\text { methods to } \\
\text { teach students } \\
\text { (in presenting } \\
\text { content, } \\
\text { engaging } \\
\text { students, or } \\
\text { assessing } \\
\text { learning). The } \\
\text { candidate } \\
\text { adapts } \\
\text { instruction to } \\
\text { help students } \\
\text { learn. }\end{array}$ & $\begin{array}{l}\text { Consistently uses } \\
\text { multiple means of } \\
\text { presenting content, } \\
\text { engaging students, } \\
\text { and assessing } \\
\text { progress in order } \\
\text { to teach all } \\
\text { students in } \\
\text { developmentally } \\
\text { appropriate ways. }\end{array}$ & $\begin{array}{l}\text { Lesson Plans } \\
\text { Assessments } \\
\text { Reflections } \\
\text { Curriculum } \\
\text { plans. } \\
\text { Observation } \\
\text { plans. }\end{array}$ \\
\hline
\end{tabular}




\begin{tabular}{|c|c|c|c|c|c|}
\hline $\begin{array}{l}\text { Indicator } \\
\text { The teacher } \\
\text { candidate, in a } \\
\text { professional } \\
\text { and ethical } \\
\text { manner,: }\end{array}$ & $\begin{array}{l}\text { Unacceptable } \\
\text { (1) }\end{array}$ & $\begin{array}{l}\text { Satisfactory (2) } \\
\text { Novice Teacher }\end{array}$ & $\begin{array}{l}\text { Proficient (3) } \\
\text { Novice Teacher }\end{array}$ & $\begin{array}{l}\text { Exemplary (4) } \\
\text { Experienced } \\
\text { Teacher, rare to be } \\
\text { seen in student } \\
\text { teaching }\end{array}$ & $\begin{array}{l}\text { Possible } \\
\text { Evidence }\end{array}$ \\
\hline $\begin{array}{l}8 . \\
\text { Appropriately } \\
\text { integrates } \\
\text { instructional } \\
\text { resources, } \\
\text { including } \\
\text { technology, into } \\
\text { the curriculum } \\
\text { to support } \\
\text { student } \\
\text { learning. } \\
\text { [IC4: } \\
\text { resourceful] }\end{array}$ & $\begin{array}{l}\text { Does not } \\
\text { integrate } \\
\text { resources, } \\
\text { including } \\
\text { technology, into } \\
\text { the curriculum } \\
\text { or does so in a } \\
\text { manner that } \\
\text { does not } \\
\text { support student } \\
\text { learning. }\end{array}$ & $\begin{array}{l}\text { Effectively } \\
\text { integrates a } \\
\text { variety of } \\
\text { appropriate } \\
\text { instructional } \\
\text { resources, } \\
\text { including } \\
\text { available } \\
\text { technology, into } \\
\text { the curriculum. }\end{array}$ & $\begin{array}{l}\text { Uses a variety } \\
\text { of instructional } \\
\text { resources, } \\
\text { including } \\
\text { technology, on } \\
\text { a regular basis, } \\
\text { to enhance the } \\
\text { delivery of the } \\
\text { content and } \\
\text { make the } \\
\text { content } \\
\text { accessible to all } \\
\text { students. }\end{array}$ & $\begin{array}{l}\text { Uses a wide variety } \\
\text { of instructional } \\
\text { resources, } \\
\text { including } \\
\text { technology, } \\
\text { consistently and } \\
\text { effectively in } \\
\text { designing, } \\
\text { implementing, and } \\
\text { assessing } \\
\text { meaningful } \\
\text { learning activities. }\end{array}$ & $\begin{array}{l}\text { Computer } \\
\text { programs } \\
\text { Essays, } \\
\text { Interviews } \\
\text { Individual plans } \\
\text { Observation } \\
\text { reports } \\
\text { Journals, } \\
\text { Pictures } \\
\text { Lesson plans }\end{array}$ \\
\hline $\begin{array}{l}\text { 9. Uses } \\
\text { multiple } \\
\text { assessment } \\
\text { strategies. } \\
\text { [EC3: regard for } \\
\text { learning] }\end{array}$ & $\begin{array}{l}\text { Uses limited } \\
\text { materials, media } \\
\text { and strategies to } \\
\text { assess individual } \\
\text { and group } \\
\text { achievement. }\end{array}$ & $\begin{array}{l}\text { Uses a variety of } \\
\text { materials, media } \\
\text { and strategies to } \\
\text { assess individual } \\
\text { and group } \\
\text { achievement. }\end{array}$ & $\begin{array}{l}\text { Uses a variety } \\
\text { of materials, } \\
\text { media, and } \\
\text { strategies to } \\
\text { assess student } \\
\text { learning and } \\
\text { uses reflection } \\
\text { on assessment } \\
\text { findings to } \\
\text { guide future } \\
\text { instruction, i.e., } \\
\text { practices data- } \\
\text { driven decision- } \\
\text { making. }\end{array}$ & $\begin{array}{l}\text { Uses a variety of } \\
\text { materials, media, } \\
\text { and strategies to } \\
\text { continually assess } \\
\text { student learning } \\
\text { and uses findings } \\
\text { to guide decisions } \\
\text { for short- and long- } \\
\text { term planning, i.e., } \\
\text { practices data- } \\
\text { driven decision- } \\
\text { making. }\end{array}$ & $\begin{array}{l}\text { Portfolio } \\
\text { Assessments } \\
\text { Projects } \\
\text { Bulletin boards } \\
\text { Student work } \\
\text { samples } \\
\text { Teacher-made } \\
\text { materials }\end{array}$ \\
\hline
\end{tabular}




\begin{tabular}{|c|c|c|c|c|c|}
\hline $\begin{array}{l}\text { Indicator } \\
\text { The teacher } \\
\text { candidate, in a } \\
\text { professional } \\
\text { and ethical } \\
\text { manner,: }\end{array}$ & $\begin{array}{l}\text { Unacceptable } \\
\text { (1) }\end{array}$ & $\begin{array}{l}\text { Satisfactory (2) } \\
\text { Novice Teacher }\end{array}$ & $\begin{array}{l}\text { Proficient (3) } \\
\text { Novice Teacher }\end{array}$ & $\begin{array}{l}\text { Exemplary (4) } \\
\text { Experienced } \\
\text { Teacher, rare to be } \\
\text { seen in student } \\
\text { teaching }\end{array}$ & $\begin{array}{l}\text { Possible } \\
\text { Evidence }\end{array}$ \\
\hline $\begin{array}{l}\text { 10. Uses } \\
\text { reflection to } \\
\text { improve } \\
\text { instruction. } \\
\text { [IC5: } \\
\text { enthusiasm; } \\
\text { EC3: regard for } \\
\text { learning] }\end{array}$ & $\begin{array}{l}\text { Does not reflect } \\
\text { and write action } \\
\text { statements } \\
\text { showing intent } \\
\text { to improve } \\
\text { learning } \\
\text { experiences } \\
\text { based on } \\
\text { information } \\
\text { gained from } \\
\text { previous lessons } \\
\text { and supervisor } \\
\text { feedback. }\end{array}$ & $\begin{array}{l}\text { Reflects and } \\
\text { writes action } \\
\text { statements } \\
\text { showing intent } \\
\text { to improve } \\
\text { learning } \\
\text { experiences } \\
\text { based on } \\
\text { information } \\
\text { gained from } \\
\text { previous lessons } \\
\text { and supervisor } \\
\text { feedback. }\end{array}$ & $\begin{array}{l}\text { Reflects and } \\
\text { writes action } \\
\text { statements } \\
\text { showing intent } \\
\text { to improve } \\
\text { learning } \\
\text { experiences } \\
\text { based on } \\
\text { information } \\
\text { gained from } \\
\text { previous } \\
\text { lessons and } \\
\text { supervisor } \\
\text { feedback and } \\
\text { implements } \\
\text { those changes } \\
\text { in subsequent } \\
\text { lessons. }\end{array}$ & $\begin{array}{l}\text { Reflects and writes } \\
\text { action statements } \\
\text { showing intent to } \\
\text { improve learning } \\
\text { experiences and } \\
\text { implements those } \\
\text { changes in } \\
\text { subsequent } \\
\text { lessons. The } \\
\text { candidate also } \\
\text { makes appropriate } \\
\text { changes while } \\
\text { teaching based on } \\
\text { student response. }\end{array}$ & $\begin{array}{l}\text { Lesson plans } \\
\text { Videos, } \\
\text { Reflective } \\
\text { Essays } \\
\text { Cooperating } \\
\text { Teacher and } \\
\text { University } \\
\text { Supervisor's } \\
\text { feedback }\end{array}$ \\
\hline $\begin{array}{l}11 . \\
\text { Demonstrates } \\
\text { persistence in } \\
\text { helping all } \\
\text { students learn. } \\
\text { [EC3: regard for } \\
\text { learning; IC5: } \\
\text { enthusiasm; } \\
\text { EC4: respect for } \\
\text { learners] }\end{array}$ & $\begin{array}{l}\text { Gives up after } \\
\text { one attempt } \\
\text { and/or } \\
\text { attributes } \\
\text { inadequate } \\
\text { student } \\
\text { achievement to } \\
\text { external factors } \\
\text { (e.g., family, } \\
\text { social context, } \\
\text { students won't } \\
\text { try). }\end{array}$ & $\begin{array}{l}\text { Seeks additional } \\
\text { approaches and } \\
\text { strategies with } \\
\text { the intent to } \\
\text { help all students } \\
\text { learn. }\end{array}$ & $\begin{array}{l}\text { Is persistent in } \\
\text { using a variety } \\
\text { of approaches } \\
\text { and strategies } \\
\text { to help all } \\
\text { students learn } \\
\text { and provides } \\
\text { remediation as } \\
\text { suggested by } \\
\text { assessment. }\end{array}$ & $\begin{array}{l}\text { Persistently uses a } \\
\text { variety of } \\
\text { approaches, } \\
\text { including } \\
\text { remediation, and } \\
\text { draws upon both } \\
\text { internal and } \\
\text { external resources } \\
\text { to support and } \\
\text { sustain student } \\
\text { learning whenever } \\
\text { appropriate. }\end{array}$ & $\begin{array}{l}\text { Reflections } \\
\text { Lesson Plans } \\
\text { IEPs } \\
\text { Referrals } \\
\text { Supervisor } \\
\text { Reports }\end{array}$ \\
\hline
\end{tabular}




\begin{tabular}{|c|c|c|c|c|c|}
\hline $\begin{array}{l}\text { Indicator } \\
\text { The teacher } \\
\text { candidate, in a } \\
\text { professional } \\
\text { and ethical } \\
\text { manner,: }\end{array}$ & $\begin{array}{l}\text { Unacceptable } \\
\text { (1) }\end{array}$ & $\begin{array}{l}\text { Satisfactory (2) } \\
\text { Novice Teacher }\end{array}$ & $\begin{array}{l}\text { Proficient (3) } \\
\text { Novice Teacher }\end{array}$ & $\begin{array}{l}\text { Exemplary (4) } \\
\text { Experienced } \\
\text { Teacher, rare to be } \\
\text { seen in student } \\
\text { teaching }\end{array}$ & $\begin{array}{l}\text { Possible } \\
\text { Evidence }\end{array}$ \\
\hline $\begin{array}{l}\text { 12. Uses } \\
\text { assessment to } \\
\text { demonstrate } \\
\text { positive impact } \\
\text { on student } \\
\text { learning. } \\
\text { [EC3: regard for } \\
\text { learning; EC4: } \\
\text { respect for } \\
\text { learners] }\end{array}$ & $\begin{array}{l}\text { Selects activities } \\
\text { that do not } \\
\text { promote } \\
\text { progress with } \\
\text { respect to } \\
\text { intended } \\
\text { learning } \\
\text { outcomes } \\
\text { and/or does not } \\
\text { know how to } \\
\text { determine } \\
\text { whether } \\
\text { students are } \\
\text { progressing. }\end{array}$ & $\begin{array}{l}\text { Assesses } \\
\text { sporadically but } \\
\text { does not } \\
\text { consistently } \\
\text { incorporate } \\
\text { results into } \\
\text { subsequent } \\
\text { instructional } \\
\text { planning. }\end{array}$ & $\begin{array}{l}\text { Routinely uses } \\
\text { multiple } \\
\text { sources of } \\
\text { evidence to } \\
\text { demonstrate } \\
\text { progress with } \\
\text { respect to } \\
\text { intended } \\
\text { learning } \\
\text { outcomes and } \\
\text { considers } \\
\text { results in } \\
\text { planning. }\end{array}$ & $\begin{array}{l}\text { Uses both } \\
\text { formative and } \\
\text { summative } \\
\text { measures to assess } \\
\text { for positive impact. } \\
\text { The candidate } \\
\text { systematically } \\
\text { plans for pre- and } \\
\text { post- assessments, } \\
\text { analyzes for } \\
\text { evidence of } \\
\text { progress with } \\
\text { respect to intended } \\
\text { learning outcomes, } \\
\text { and modifies } \\
\text { instruction as } \\
\text { needed. }\end{array}$ & $\begin{array}{l}\text { Observations, } \\
\text { Journal writing } \\
\text { Pre-test/ Post- } \\
\text { test } \\
\text { Teacher Work } \\
\text { Samples } \\
\text { Student Work } \\
\text { Samples }\end{array}$ \\
\hline
\end{tabular}




\begin{tabular}{|c|c|c|c|c|c|}
\hline $\begin{array}{l}\text { Indicator } \\
\text { The teacher } \\
\text { candidate, in } \\
\text { a professional } \\
\text { and ethical } \\
\text { manner,: }\end{array}$ & Unacceptable (1) & $\begin{array}{l}\text { Satisfactory (2) } \\
\text { Novice Teacher }\end{array}$ & $\begin{array}{l}\text { Proficient (3) } \\
\text { Novice Teacher }\end{array}$ & $\begin{array}{l}\text { Exemplary (4) } \\
\text { Experienced } \\
\text { Teacher, rare to } \\
\text { be seen in } \\
\text { student teaching }\end{array}$ & $\begin{array}{l}\text { Possible } \\
\text { Evidence }\end{array}$ \\
\hline \multicolumn{6}{|c|}{ Regarding interpersonal skills } \\
\hline $\begin{array}{l}13 . \\
\text { Demonstrates } \\
\text { respect for all } \\
\text { students. } \\
\text { [EC4: respect } \\
\text { for learners; } \\
\text { EC1: } \\
\text { sensitivity- } \\
\text { diversity] }\end{array}$ & $\begin{array}{l}\text { Displays } \\
\text { disparaging or } \\
\text { offensive } \\
\text { attitudes and } \\
\text { perceptions } \\
\text { toward students } \\
\text { and/or families. } \\
\text { Engages } \\
\text { developmentally } \\
\text { inappropriate } \\
\text { expectations and } \\
\text { practices such as } \\
\text { disrespectful or } \\
\text { insensitive } \\
\text { interactions, } \\
\text { humiliation or } \\
\text { unjust } \\
\text { treatment. }\end{array}$ & $\begin{array}{l}\text { Values students } \\
\text { as individuals by } \\
\text { fostering an } \\
\text { environment } \\
\text { based on } \\
\text { developmentally } \\
\text { appropriate } \\
\text { expectations and } \\
\text { respectful } \\
\text { interactions. }\end{array}$ & $\begin{array}{l}\text { Values students } \\
\text { as individuals } \\
\text { and as members } \\
\text { of the learning } \\
\text { community by } \\
\text { fostering an } \\
\text { inclusive } \\
\text { environment } \\
\text { based on } \\
\text { developmentally } \\
\text { appropriate } \\
\text { expectations, } \\
\text { respectful } \\
\text { interaction, and } \\
\text { justice. }\end{array}$ & $\begin{array}{l}\text { Values students } \\
\text { as individuals } \\
\text { and as partners } \\
\text { in the learning } \\
\text { community by } \\
\text { fostering an } \\
\text { inclusive } \\
\text { environment } \\
\text { based on } \\
\text { developmentally } \\
\text { appropriate } \\
\text { expectations, } \\
\text { respectful } \\
\text { interaction, } \\
\text { justice, } \\
\text { cooperation, } \\
\text { responsibility, } \\
\text { and team work. }\end{array}$ & $\begin{array}{l}\text { Reflective } \\
\text { journals } \\
\text { Lesson Plans } \\
\text { Video of lessons } \\
\text { Supervisor's } \\
\text { Report }\end{array}$ \\
\hline $\begin{array}{l}\text { 14. Develops } \\
\text { positive } \\
\text { working } \\
\text { relationships } \\
\text { with others } \\
\text { involved in the } \\
\text { educational } \\
\text { setting. } \\
\text { [EC2: } \\
\text { collaboration] }\end{array}$ & $\begin{array}{l}\text { Has limited } \\
\text { positive } \\
\text { interaction with } \\
\text { others and/or } \\
\text { interpersonal } \\
\text { conduct hinders } \\
\text { professional } \\
\text { relationships to } \\
\text { serve students } \\
\text { effectively. }\end{array}$ & $\begin{array}{l}\text { Interacts and } \\
\text { cooperates with } \\
\text { other teachers } \\
\text { courteously and } \\
\text { respectfully to } \\
\text { promote } \\
\text { professional } \\
\text { relationships. }\end{array}$ & $\begin{array}{l}\text { Cultivates } \\
\text { positive } \\
\text { interactions that } \\
\text { extend to } \\
\text { support staff, } \\
\text { school } \\
\text { volunteers, other } \\
\text { specialists, } \\
\text { and/or } \\
\text { community } \\
\text { professionals to } \\
\text { serve students } \\
\text { more effectively. }\end{array}$ & $\begin{array}{l}\text { Collaborates } \\
\text { regularly with a } \\
\text { variety of } \\
\text { individuals to } \\
\text { enhance practice } \\
\text { and serve } \\
\text { students } \\
\text { effectively. }\end{array}$ & $\begin{array}{l}\text { Involvement in } \\
\text { team or other } \\
\text { Professional } \\
\text { meetings } \\
\text { Cooperating } \\
\text { Teacher reports } \\
\text { University } \\
\text { Supervisor } \\
\text { reports } \\
\text { Written } \\
\text { communications } \\
\text { Peer critique } \\
\text { Team developed } \\
\text { and taught } \\
\text { lesson plans }\end{array}$ \\
\hline
\end{tabular}




\begin{tabular}{|c|c|c|c|c|c|}
\hline $\begin{array}{l}\text { Indicator } \\
\text { The teacher } \\
\text { candidate, in } \\
\text { a professional } \\
\text { and ethical } \\
\text { manner,: }\end{array}$ & Unacceptable (1) & $\begin{array}{l}\text { Satisfactory (2) } \\
\text { Novice Teacher }\end{array}$ & $\begin{array}{l}\text { Proficient (3) } \\
\text { Novice Teacher }\end{array}$ & $\begin{array}{l}\text { Exemplary (4) } \\
\text { Experienced } \\
\text { Teacher, rare to } \\
\text { be seen in } \\
\text { student teaching }\end{array}$ & $\begin{array}{l}\text { Possible } \\
\text { Evidence }\end{array}$ \\
\hline $\begin{array}{l}\text { 15. Includes } \\
\text { families in the } \\
\text { education } \\
\text { process. } \\
\text { [EC2: } \\
\text { collaboration; } \\
\text { IC4: } \\
\text { resourceful] }\end{array}$ & $\begin{array}{l}\text { Shows no } \\
\text { evidence of } \\
\text { interaction with } \\
\text { families. }\end{array}$ & $\begin{array}{l}\text { Engages in some } \\
\text { outreach } \\
\text { attempts, (e.g., } \\
\text { parent/teacher } \\
\text { conferences, } \\
\text { written } \\
\text { communications, } \\
\text { phone } \\
\text { conversations). }\end{array}$ & $\begin{array}{l}\text { Implements a } \\
\text { plan to include } \\
\text { families in the } \\
\text { educational } \\
\text { process (e.g., } \\
\text { web-based, } \\
\text { schedule of } \\
\text { conference } \\
\text { opportunities, } \\
\text { variety of } \\
\text { activities). }\end{array}$ & $\begin{array}{l}\text { Diligently seeks } \\
\text { opportunities to } \\
\text { interact with } \\
\text { families with the } \\
\text { intent of } \\
\text { incorporating } \\
\text { them into the } \\
\text { educational } \\
\text { process. }\end{array}$ & $\begin{array}{l}\text { Attendance at } \\
\text { PTO meetings or } \\
\text { other family } \\
\text { school functions } \\
\text { Phone Logs } \\
\text { Newsletters }\end{array}$ \\
\hline
\end{tabular}




\section{APPENDIX B}

\section{PRESERVICE TEACHER PERCEPTION SURVEY}

Pre-Survey - Before beginning student-teaching experience

You are invited to participate in a small study to discover whether differences exist between traditional preservice teachers (those who entered college immediately after graduating from high school) and non-traditional preservice teachers (those who are returning to college to pursue a new degree in teaching). The results of this study may impact future design of teacher education programs. A direct benefit to you is the opportunity to reflect upon your preservice teaching so far. The risk is minimal, as the only imaginable possible discomfort might be some anxiety surfacing as a result of reflecting on your preservice teaching. The survey consists of 27 questions with simple choices and a Likert scale. The questions are related to preservice teaching and correlate directly to the Realizing the Democratic Ideal. The survey should take less than 10 minutes of your time.

This survey is about your anticipations and expectations of your studentteaching experience. At the end of the semester, you will be asked to take another short survey with exactly the same questions in exactly the same order, to see to what degree your concluding perceptions aligned with your expectations about your student-teaching experience.

Another piece of this study includes matching participants' survey answers to their preservice evaluations provided by their university supervisors and their cooperating teachers. ULIDs will be necessary to match surveys to evaluations, but immediately after the match, all identifiers will be destroyed and replaced with random numbers. You will be given the opportunity to participate with a separate form of consent at the end of the semester.

If you have any questions or concerns, please feel free to contact me, Cynthia Schairer-Kessler, at cjschai@ilstu.edu, or my doctoral committee chair, Dr. Nancy Latham at nilatha@ilstu.edu. In addition, for questions about research participants' rights and/or a research related injury or adverse effects, notify the Research Ethics \& Compliance Office at (309) 438-2529 and/or rec@ilstu.edu. 
Your participation is greatly appreciated and completely voluntary. You can recuse yourself from participating at any time with absolutely no risk or penalty.

Thank you for your cooperation, and sincere best wishes for your studentteaching experience. 
Pre-Survey - before beginning student-teaching experience

Directions for Professional Demeanor section: Please choose the option that best describes you.

Professional Demeanor
1. Strongly Disagree
2. Disagree
3. Agree
4. Strongly Agree

1. I will demonstrate specialized content knowledge for teaching

2. I will communicate effectively (written, verbal, nonverbal)

3. I will use effective classroom management skills to maintain safe and positive learning environments

4. I will feel like a "real teacher" during my student teaching

5. I can't wait to get my own classroom so I can teach my way

6. I am apprehensive about being in my own classroom

Directions for Teaching and Learning section: Please choose the option that best describes you.

Teaching and Learning

$\begin{array}{lll}\text { 1. Strongly Disagree } & \text { 2. Disagree } & 3 \text {. Agree } \quad 4 \text {. Strongly Agree }\end{array}$

7. I will plan and develop lessons to meet instructional goals and serve diverse learners

8. I will differentiate instruction

9. I will appropriately integrate instructional resources, including technology, into the curriculum to support student learning

10. I will use multiple assessment strategies

11. I will use reflection to improve instruction

12.I will demonstrate persistence in helping all students learn

13.I will demonstrate a positive impact on student learning

14. I will create my own lessons

15. I will use someone else's lessons but rework them to fit my needs

16. I will use someone else's lessons as they are 
Directions for Interpersonal Skills section: Please choose the option that best describes you.

Interpersonal Skills
1. Strongly Disagree
2. Disagree
3. Agree
4. Strongly Agree

17.I will demonstrate respect for all students

18. I will develop positive working relationships with others involved in the educational setting

19. I will include families in the education process

20. I will find it difficult to fit in with the other teachers

21. I will find it easy to work with other teachers

22. My cooperating teacher will help me immensely

Directions for Time-Management Skills section: Please choose the option that best describes you.

Time-Management Skills
1. Strongly Disagree
2. Disagree
3. Agree 4. Strongly Agree

23. I will be able to manage my time at the school effectively

24. I will be able to manage my time outside the school effectively

25. Hours outside school I anticipate I will spend planning instruction per week

fill in number

26. Hours outside school I anticipate I will spend assessing student progress per week

fill in number

27. Hours outside school I anticipate I will spend performing other educational tasks related to student-teaching

fill in number 
Post-Survey - After completing student-teaching experience

You chose to participate in a small study to discover whether differences exist between traditional preservice teachers (those who entered college immediately after graduating from high school) and non-traditional preservice teachers (those who are returning to college to pursue a new degree in teaching). The results of this study may impact future design of teacher education programs. A direct benefit to you is the opportunity to reflect upon your preservice teaching so far. The risk is minimal, as the only imaginable possible discomfort might be some anxiety surfacing as a result of reflecting on your preservice teaching. The survey consists of 2 questions with simple choices and a Likert scale. The questions are related to preservice teaching and correlate directly to the Realizing the Democratic Ideal. The survey should take about less than 10 minutes of your time.

This survey is about your perceptions of your student-teaching experience. At the beginning of the semester, you already took a brief survey with exactly the same questions in exactly the same order. Today's survey will illuminate the degree to which your concluding perceptions align with your beginning expectations about your student-teaching experience.

Another piece of this study includes matching participants' survey answers to their preservice evaluations provided by their university supervisors and their cooperating teachers. ULIDs will be necessary to match surveys to evaluations, but immediately after the match, all identifiers will be destroyed and replaced with random numbers. You will be given the opportunity to participate with a separate form of consent at the end of the semester.

If you have any questions or concerns, please feel free to contact me, Cynthia Schairer-Kessler, at cjschai@ilstu.edu, or my doctoral committee chair, Dr. Nancy Latham at nilatha@ilstu.edu. In addition, for questions about research participants' rights and/or a research related injury or adverse effects, notify the Research Ethics \& Compliance Office at (309) 438-2529 and/or rec@ilstu.edu.

Your participation is greatly appreciated and completely voluntary. You can recuse yourself from participating at any time with absolutely no risk or penalty.

Thank you for your cooperation, and sincere best wishes for your teaching career. 
Post-Survey - After completing the student-teaching experience

Directions for Professional Demeanor section: Please choose the option that best describes you.

Professional Demeanor
1. Strongly Disagree
2. Disagree
3. Agree
4. Strongly Agree

1. I demonstrated specialized content knowledge for teaching

2. I communicated effectively (written, verbal, nonverbal)

3. I used effective classroom management skills to maintain safe and positive learning environments

4. I felt like a "real teacher" during my student teaching

5. I can't wait to get my own classroom so I can teach my way

6. I am apprehensive about being in my own classroom

Directions for Teaching and Learning section: Please choose the option that best describes you.

Teaching and Learning
1. Strongly Disagree
2. Disagree
3. Agree
4. Strongly Agree

7. I planned and developed lessons to meet instructional goals and serve diverse learners

8. I differentiated instruction

9. I appropriately integrated instructional resources, including technology, into the curriculum to support student learning

10.I used multiple assessment strategies

11.I used reflection to improve instruction

12.I demonstrated persistence in helping all students learn

13.I demonstrated a positive impact on student learning

14.I created my own lessons

15. I used someone else's lessons but reworked them to fit my needs

16.I used someone else's lessons as they were 
Directions for Interpersonal Skills section: Please choose the option that best describes you.

Interpersonal Skills
1. Strongly Disagree
2. Disagree
3. Agree
4. Strongly Agree

17. I demonstrated respect for all students

18. I developed positive working relationships with others involved in the educational setting

19.I included families in the education process

20.I found it difficult to fit in with the other teachers

21.I found it easy to work with other teachers

22. My cooperating teacher helped me immensely

Directions for Time-Management Skills section: Please choose the option that best describes you.

Time-Management Skills
1. Strongly Disagree
2. Disagree
3. Agree
4. Strongly Agree

23. I was able to manage my time at the school effectively

24. I was able to manage my time outside the school effectively

25. Hours outside school spent planning instruction per week

fill in number

26. Hours outside school spent assessing student progress per week

fill in number

27. Hours outside school spent performing other educational tasks related to student-teaching

fill in number 


\section{Preservice Teacher Study}

You are invited to participate in a small study to discover whether differences exist between traditional preservice teachers (those who entered college immediately after graduating from high school) and non-traditional preservice teachers (those who are returning to college to pursue a new degree in teaching). The results of this study may impact future design of teacher education programs. A direct benefit to you is the opportunity to reflect upon your preservice teaching so far. The risk is minimal, as the only imaginable possible discomfort might be some anxiety surfacing as a result of sharing your studentteaching evaluations with the researcher.

You have already completed two brief surveys, one before beginning your student teaching and one after completing it.

The final piece of this study includes matching participants' survey answers to their preservice evaluations provided by their university supervisors and their cooperating teachers. ULIDs will be necessary to match surveys to evaluations, but immediately after the match, all identifiers will be destroyed and replaced with random numbers.

Choosing the "I Agree" option will indicate your consent to the access of your preservice evaluation. If you have any questions or concerns, please feel free to contact me, Cynthia Schairer-Kessler, at cjschai@ilstu.edu, or my doctoral committee chair, Dr. Nancy Latham at nilatha@ilstu.edu. In addition, for questions about research participants' rights and/or a research related injury or adverse effects, notify the Research Ethics \& Compliance Office at (309) 4382529 and/or rec@ilstu.edu.

Your participation is greatly appreciated and completely voluntary. You can recuse yourself from participating at any time with absolutely no risk or penalty.

Thank you for your cooperation, and sincere best wishes for your teaching career.

1. I Agree -- to allow the researcher access to my student-teaching evaluation

2. I Do Not Agree - to allow the researcher access to my student-teaching evaluation 